REVISTA DE DERECHO UNED, NÚM. 21, 2017

\title{
ARMONÍA Y CONFLICTO EN LA CONFLUENCIA DE LEALTADES DE LOS CARGOS REPRESENTATIVOS
}

\author{
HARMONY AND CONFLICT IN THE CONFLUENCE \\ OF REPRESENTATIVE'S LOYALTIES
}

\author{
AleXandre H. Català i Bas \\ Profesor titular de Derecho Constitucional \\ Universidad de Valencia
}

Resumen: La lealtad es un principio, no el único, presente en las relaciones políticas. Supone un compromiso y la asunción de obligaciones jurídicas y éticas. Si el cargo representativo incumple ese deber de fidelidad es calificado de desleal o traidor.

Un cargo representativo asume varias lealtades: hacia la Constitución, hacia el partido y su líder y hacia el electorado. Estas lealtades pueden confluir de forma armónica o entrar en conflicto, de manera que para mantener una se rompa con las otras.

El presente trabajo analiza las diferentes lealtades que asume un cargo representativo e intenta establecer una graduación entre ellas partiendo de la hipótesis de que tienen diferente valor.

Abstract: Loyalty is a principle, not the only one, which is present in political relations. It implies a commitment and the assumption of legal and ethical obligations. If the representative fails to fulfil this duty of fidelity, it is described as disloyal or traitorous.

A representative assumes several loyalties: towards the Constitution, towards the party and its leader and towards the electorate. These loyalties can come together harmoniously, or on the contrary by in conflict, so that keeping one would prevent from keeping the others. 
The present work analyses the different loyalties that assume a representative and intends to establish a graduation between them starting from the hypothesis that they have different value.

Key Words: Representative, constitutional loyalty, democratic loyalty, loyalty to the political party, loyalty to the electorate.

Palabras clave: Cargo representativo, lealtad constitucional, lealtad democrática, lealtad al partido político, lealtad al electorado.

Recepción original: 07/06/2017

Aceptación original: 27/10/2017

Sumario: I. La lealtad y la deslealtad en el ámbito político. II. Lealtad constitucional, lealtad democrática y cargos representativos. III. La lealtad de los cargos representativos a los partidos políticos. IV. La lealtad del cargo representativo con el electorado. V. ¿Es posible establecer una graduación de lealtades del cargo representativo? VI. ¿La lealtad democrática en peligro? Una breve reflexión final.

\section{LA LEALTAD Y LA DESLEALTAD EN EL ÁMBITO POLÍTICO}

La lealtad es un principio, no el único, que subyace en las relaciones políticas. De acuerdo con la primera acepción de la R. A. E. por tal cabe entender «cumplimiento de lo que exigen las leyes de la fidelidad»; por su parte, la primera acepción de fidelidad, a su vez, nos remite a la lealtad: «lealtad, observancia de la fe que alguien debe a otra persona». Y como afirma Touraine, «el poder político ha impuesto manifestaciones de pertenencia y de lealtad ${ }^{1}$.

Por de pronto, podemos afirmar que la lealtad, en cualquier ámbito de la vida, público o privado, tiene carácter relacional pues exige un sujeto emisor del compromiso y un receptor de éste. En unos casos existirá reciprocidad; en otros, en cambio, sólo unidireccionalidad. En unos casos, esa lealtad vendrá exigida por el ordenamiento jurídico; en otros, ese compromiso será asumido de forma voluntaria. En unos, se dará en el marco de una relación horizontal en la que las partes están en una situación de igualdad; en otros, en el de una relación vertical pues existirá una situación de superioridad de una de ellas que podrá imponer los términos de dicha lealtad.

La lealtad supone un compromiso y como tal puede incumplirse. En este caso hablamos de deslealtad e, incluso, de traición pues de acuerdo con la RAE por tal cabe entender «falta que se comete que-

${ }^{1}$ Touraine, Alain: «¿Qué es la democracia?», Ensayo, 1994, pág. 31. 
brantando la fidelidad o lealtad que se debe guardar o tener». Las razones que pueden llevar a la deslealtad pueden ser varias y no todas merecedoras del calificativo de espurias. Así, la ruptura del compromiso puede tener por objeto obtener una contraprestación o porque faltar, negar u ocultar dicha relación reporta, de repente, mayores ventajas que mantenerla o reconocerla. Pero también puede deberse a razones éticas cuando una de las partes no puede moralmente mantener la palabra dada. Desgraciadamente la realidad nos muestra que en la mayoría de los casos se debe a circunstancias del primer tipo. Como señala Max Weber, «La adhesión puede fingirse por individuos y grupos enteros por razones de oportunidad, practicarse efectivamente por intereses materiales propios o aceptarse como algo irremediable en virtud de debilidades individuales y de desvalimiento ${ }^{2}$.

En el ámbito político la lealtad exige un actor político que emite ese compromiso y alguien, otro actor político o algo, una Constitución, que lo recibe. Desde la antigüedad este principio ha estado presente y ha exigido respetar los términos del pacto, pacta sunt servan$d a$. Ya en el Código de Amurabi se le advierte al rey que si no respeta las leyes «Enhil, el Señor, cuyas leyes no pueden ser alteradas haga recaer sobre él, contra su trono, una revuelta indomable, una rebeldía que le acarree la ruina» (XXVI, 50). En el Antiguo Testamento, en concreto, en el Libro de los Números se describe cómo los israelitas son castigados a vagar por el desierto como consecuencia de haber roto su pacto con Yahvé (Núm. 20,1). En la Antigua Roma la lealtad se garantizaba por vía religiosa con el culto al emperador. El cristianismo dirá: «Dad al César lo que es del César y a Dios lo que es de Dios» (Lucas, 20:25). Se planteará aquí una doble lealtad que entrará en conflicto, resolviéndose por el cristiano dando preferencia a la lealtad a Dios y no reconociendo el carácter divino del emperador, negándose, por tanto, a adorarlo. Como señala Sabine, "para el cristiano, los deberes religiosos constituían una obligación suprema, debida directamente a Dios y eran resultado de la relación entre una deidad espiritual y la esencia espiritual de la naturaleza humana. La interferencia de una fuerza terrena en esa relación, era algo que, en principio, un cristiano no debía tolerar, y por esa razón, la ceremonia enteramente formal de tributar al emperador honores religiosos, constituía una exigencia a la que debía negarse» ${ }^{3}$.

${ }^{2}$ Weber, Max: Economía y Sociedad, Fondo de Cultura Económica, 1992, reimpresión 1969, pág. 171.

${ }^{3}$ SABInE, George: Historia de la teoría política, Fondo de Cultura Económica, decimonovena reimpresión, 1990, pág. 145. 
En la Edad Media la lealtad vertebrará el sistema. Como destaca Theimer, las concepciones política de la época feudal se fundan en la relación personal entre gobernantes y gobernados. El hombre estaba ligado por un vínculo de fidelidad a un determinado «señor» inmediato, no a un «país» o «Estado» impersonal ${ }^{4}$.

Maquiavelo aconseja al Príncipe no basar su relación con los súbditos en la lealtad ya que éstos no la van a guardar con él: «Puesto que los hombres son malos por naturaleza y no van a guardar la fe que os deben, tampoco Vos estáis obligados a guardársela a ellos» (El Príncipe XVIII, Quo modo fides a principibus sit servanda). En la literatura posterior, la fidelidad estará implícita en las relaciones entre gobernantes y gobernados. Los primeros deben ejercer un gobierno justo, los segundos obedecer. Hobbes negará el derecho de resistencia, cosa que sí reconocerán autores como Mariana, Suárez, Loke e incluso Bodino. Así encontramos la obra Vindiciae contra tyrannos o el Acta de abjuración mediante la cual los Estados Generales de los Países Bajos revocaron su lealtad al rey español Felipe II.

En los parlamentos medievales, el representante estaba sujeto a mandato imperativo lo que le obligaba a ser fiel a las instrucciones recibidas so pena de ser destituido del cargo. En Inglaterra, como recuerda Torres del Moral, los mandantes no podían prever todos los giros de las negociaciones de sus representantes ni estar reunidos continuamente para hacerles llegar sus instrucciones. Ante esta situación el rey exigía en sus cartas de convocatoria que los representantes llevaran amplios poderes para poder ultimar todos los asuntos y que no quedaran paralizados por falta de poderes de los representantes ${ }^{5}$. Irá así diluyéndose paulatinamente el mandato imperativo y con él el principio de lealtad que pasa a un segundo plano cobrando fuerza el de confianza (trust) que el representado debía tener en el representante. En el Agreement of the People de 1653 se puede leer que se da «por supuesto que los representantes tenían la suprema confianza en orden al cuidado del conjunto». En 1744 Burke en su Spech to Electors of Bristol manifiesta que «es conservando la independencia de mis opiniones... como yo me esforzaré a responder a esta distinción tan honorable de la confianza de mis ciudadanos».

En Francia Montesquieu en su De l'esprit des lois, defiende la libertad de los representantes a la hora de tomar las decisiones. Estos no lo son de ningún grupo sino de la nación por lo que no pueden

\footnotetext{
${ }^{4}$ Theimer, Walter: Historia de las ideas políticas, Ariel, 1960, págs. 64 y ss.

5 TORRES DEL Moral, Antonio: «Crisis del mandato representativo en el Estado de Partidos», Revista de Derecho Político, núm. 14, 1982, pág. 9.
} 
recibir instrucciones ni ser revocados por aquellos que los han elegido, lo que se plasmará en la Declaración de Derechos de 1989, la Ley 22-XII-1789 y la Constitución de 1791.

Va abriéndose paso así el mandato representativo. Ahora bien, a nadie escapa que esa situación ideal del representante libre de cualquier tipo de presión nunca se dio. A medida que se consolidan los partidos políticos, se convierten en el elemento neurálgico de las relaciones políticas cortocircuitando la relación elector-representante. Ahora las relaciones pasarán por ellos y ya no importa tanto la confianza sino que, de nuevo, cobra fuerza la idea de lealtad pero del representante hacia el partido político, y hacia el líder de éste, instaurándose de facto un mandato de partido.

En los regímenes totalitarios ante y post Segunda Guerra Mundial, la lealtad se dirigía al líder carismático convirtiéndose en sumisión y reverencia, en lealtad ciega. Pero como advierte Weber, si dicho líder «parece abandonado de su dios o de su fuerza mágica o heroica, le falla el éxito de modo duradero y, sobre todo, si su jefatura no aporta ningún bienestar a los dominados, entonces hay la probabilidad de que su autoridad carismática se disipe» ${ }^{6}$. Mussolini y Ceaucescu son dos claros ejemplos.

La lealtad aquí tratada, la de los cargos representativos, es la que se da en democracia, exenta o, al menos, sometida a menor influencia de elementos como el miedo, el fanatismo, la referencia atávica a imaginarios colectivos, etc. La lealtad en democracia es, o debería ser, una lealtad crítica que, en último término, permita expresar su disconformidad con lo exigido, dejando así paso al desleal ético que no debería sufrir consecuencias negativas por sus desavenencias. La lealtad es un concepto metapolítico y metajurídico basado en la bona fides que exige que el compromiso sea respetado: pacta sunt servanda y las consecuencias de su incumplimiento pueden ser políticas y/o jurídicas y no en todas las relaciones políticas se aplican las mismas. En este sentido, señala Punset, refiriéndose a la lealtad constitucional, que la intensidad de la lealtad varía en función de la norma constitucional de que se trate, de sus destinatarios y de los derechos o deberes que la Constitución les otorgue o les imponga ${ }^{7}$. Por otra parte, hay que advertir que las relaciones entre los emisores del compromiso y los receptores del mismo no son unívocas. Es decir, no existe una correspondencia en que a cada elemento del primer conjunto le corres-

${ }^{6}$ WeBer, Max: Economía... op. cit., pág. 194.

${ }^{7}$ PunseT, Ramón: «Lealtad constitucional, limitación de derechos y división de poderes», Repertorio Aranzadi del Tribunal Constitucional, núm. 16, 2002, pág. 8. 
ponde inequívocamente un elemento del segundo. De esta manera, los cargos representativos deben lealtad a los partidos políticos, a los grupos municipales o parlamentarios, al electorado y a la Constitución (y ello simplificando ya que en la relación que mantiene con los partidos políticos juega un papel destacado la que se genera con el líder de éstos y si, en vez de un partido, hablamos de una coalición el análisis se hace más complejo).

Lo anterior nos hace ver que, de hecho, existe una confluencia de lealtades y que de ello puede derivar un conflicto entre ellas desde el momento en el que el cargo representativo no quiere o no puede mantener al mismo tiempo todas las lealtades a las que se obligó, lo que nos lleva a preguntarnos si todas las lealtades tienen el mismo valor $\mathrm{y}$, por ende, si todas las deslealtades el mismo desvalor; o si, por el contrario, puede establecerse una jerarquización entre ellas. De optar por la primera opción, todas las lealtades tienen el mismo valor o son de igual calidad, en caso de confrontación, en principio, no hay solución salvo que busquemos fuera de ese concepto algún elemento que haga inclinar la balanza hacia un lado u otro. Si les atribuimos diferente valor, legítimamente podrá optarse por respetar la de mayor valor y el que así se comporte no podrá ser tachado de desleal.

En este sentido, cabe preguntarse si la lealtad a la Constitución, al partido y al electorado tiene idéntico o distinto valor. De entrada, nos inclinamos por pensar que tienen diferente valor. Ello exige establecer cuáles son los criterios en base a los cuales atribuimos a una lealtad un valor superior o inferior a otra. Pero la cosa se complica ya que la lealtad no es el único elemento en una relación política, de ahí que pueden entrar en juego otros que hagan que el cargo representativo no opte por mantener la lealtad de mayor valor, lo que también nos lleva a tener en cuenta esos elementos, algunos de ellos subjetivos que caen de lleno en el campo de la ética, lo que complica aún más la cuestión. Así, Maquiavelo aconsejaba al Príncipe que «en ocasiones para defender su Estado necesitará actuar contra la lealtad, contra la caridad, contra la humanidad y la religión. (...) Haga el príncipe por dominar y conservar el Estado, que los medios siempre serán considerados justos y alabados por todos.»

Esta problemática queda aquí expuesta, pero no puede ser tratada en toda su extensión por razón de espacio. Aceptemos por un momento que la lealtad hacia el electorado sea de superior valor que la lealtad hacia el partido o que la que se debe al partido lo sea en relación con la que se profesa al líder de éste y, sin embargo, el cargo representativo se inclina por la de menor valor. En unos casos, las razones que 
le han llevado a esa decisión pueden ser espurias o fraudulentas, como asegurarse un puesto en las listas en las siguientes elecciones o un buen puesto una vez abandonada la política activa (el tan mentado fenómeno de las puertas giratorias); en otros casos, las razones pueden ser éticamente defendibles, como estar convencido de que la situación hace imposible mantener las promesas hechas al electorado y hay que ser fieles al partido votando en contra de lo prometido por ser lo mejor para los intereses generales. En esta clave puede entenderse el cambio de criterio del PSOE tras las elecciones del 26 de junio de 2016. Tras mantener ante su electorado como una promesa electoral que de ningún modo favorecerían una investidura de un gobierno del Partido Popular («no es no»), en la sesión de investidura de 29 de octubre, con su abstención propiciaron dicha investidura. Se apeló a la responsabilidad de Estado para incumplir una promesa electoral: había que terminar con la situación del bloqueo que ya duraba 10 meses y no había que ir a terceras elecciones. Si bien es cierto que existía un segundo motivo reconocido por el propio Presidente de la Gestora: unas terceras elecciones serían fatídicas, en términos electorales, para el Partido Socialista.

En definitiva, en democracia la lealtad ha de ser crítica y no tiene un carácter absoluto pues puede ceder ante otros elementos también presentes en las relaciones políticas.

\section{LEALTAD CONSTITUCIONAL, LEALTAD DEMOCRÁTICA Y CARGOS REPRESENTATIVOS}

De acuerdo con la STC 10/1983, «sólo se denominan representantes aquellos cuya designación resulta de la elección popular, esto es, aquellos cuya legitimación resulta inmediatamente de la elección de los ciudadanos».

Según Álvarez Álvarez, con la expresión lealtad constitucional «se alude a una norma o conjunto de normas constitucionales que, a modo de mandato, de permiso o prohibición, y asumiendo la estructura de principio o de regla, ejerce la función normativa consistente en dotar de eficacia normativa al contenido de uno o varios principios estructurales» ${ }^{8}$. La norma de lealtad pretende, de acuerdo con el mismo autor, construirse sobre la base de una distinción entre lo que es la infracción de las normas constitucionales que plasman la construc-

8 Álvarez Álvarez, L.: La lealtad constitucional en la Constitución española de 1978, Centro de Estudios Políticos y Constitucionales, 2008, pág. 13. 
ción de los principios estructurales (su objeto) y la infracción del resto de las normas de la Constitución ${ }^{9}$. La lealtad constitucional se erige en un instrumento de defensa de la Constitución. Ésta última, y de acuerdo con De Otto, consiste en declarar actividades que no suponen infracción de normas constitucionales ni constituyen ilícito penal pero que tienen por finalidad atacar el orden constitucional. Se trata, dicho de otro modo, de ilegalizar fines aun cuando los medios sean en sí mismos correctos. ${ }^{10} \mathrm{He}$ de poner de manifiesto cierto grado de confusión en lo manifestado por dichos autores al dar un salto entre actividades y fines que es, justamente una de las cuestiones de mayor polémica en nuestra doctrina en relación a si un partido puede ser ilegalizado por su proyecto político y si la nuestra es o no una democracia militante. El principio de lealtad constitucional encarna la pretensión normativa de una constitución de dotar de eficacia a sus principios estructurales. ${ }^{11}$ La cuestión es averiguar cuáles son los principios estructurales, sobre los que se asienta nuestra Constitución. Hay una conciencia mayoritaria de que dichos principios estarían recogidos en el artículo 1.1 que consagra el Estado de derecho y establece la superioridad de determinados valores que quedan normativizados; el segundo punto de dicho precepto que hace lo propio con la soberanía popular, el artículo 2 que establece que la unidad de la nación española es el fundamento de la Constitución, y el artículo 10.1 que reconoce que el fundamento del orden político y de la paz social se encuentran en la dignidad de la persona, los derechos fundamentales, el libre desarrollo de la personalidad, el respeto a la ley y a los derechos de los demás. Se añade por Álvarez Álvarez los principios autonómico (artículo $2 \mathrm{CE}$ ) y de integración europea (93.1 CE), añadido este último discutible, que impediría llevar a cabo un Brexit en España, de no modificarse primero la Constitución.

Para De Otto, de existir esa lealtad constitucional, esos principios son inmutables en el sentido que sobre ellos pesa una prohibición absoluta de ser modificados pues ello supone modificar el orden constitucional existente. Existe pues «un núcleo absolutamente resistente, un contenido indisponible, bien sea mediante una construcción dogmática que suple la falta de un pronunciamiento expreso del derecho constitucional positivo (...) bien sea porque así lo dice de modo ex-

${ }^{9}$ Idem pág. 15.

${ }^{10}$ OtTo, Ignacio De: Defensa de la Constitución y partidos políticos, Centro de Estudios Constitucionales, 1985, pág. 15. En sentido similar, ÁLVAREZ ÁlVAREZ, Leonardo: «Lealtad constitucional.... Op. cit. pág. 449.

${ }^{11}$ Álvarez Álvarez, L.: «Lealtad constitucional y partidos políticos», Teoría y Realidad Constitucional, núm. 10-11, 2002-2003, pág. 448. 
preso la propia norma Constitucional ${ }^{12}$, recogiendo lo mantenido por Carl Schmitt en el sentido que por defensa de la Constitución se alude a un principio interpretativo que sirve a la inmutabilidad frente al cambio de las materias sobre las que descansa el documento Constitucional positivo ${ }^{13}$.

Una Constitución establece un determinado orden constitucional, es decir, los principios o reglas sobre los que se asienta la convivencia en una sociedad. No hay que buscar ese orden constitucional fuera de la Constitución, ni buscar esos principios fuera de la Constitución. Y esos principios no son sólo de carácter procedimental, sino que, como señalan Alvarez Conde y Tur Ausina, «en la actualidad parece lógico mantener un concepto sustancialista de la Constitución, que va más allá de su consideración como norma jurídica suprema. Ello supondrá, a la postre, una opinión determinada por el propio significado del Derecho Constitucional como Derecho garantizador de la libertad y la igualdad de los seres humanos (...). Todo ello pensado que difícilmente se puede mantener un concepto neutral de Constitución alejado de todo sistema de valores e incapaz de influir en la realidad política que debe regular ${ }^{14}$. El artículo 16 de la Declaración de Derechos de Hombre y del Ciudadano, señala que «Toda sociedad en la que no esté asegurada la garantía de los derechos ni establecida la división de poderes carece de Constitución». Al respecto mantiene Torres del Moral que «el régimen constitucional nace como aquel en el que el poder político está limitado por el Derecho (encabezado por la Constitución) y ello a fin de garantizar la libertad de las personas (...) allá donde hay limitación jurídica del poder y garantía de los derechos hay Constitución y allá donde no las hay no ${ }^{15}$, para seguir diciendo que todo país tiene su régimen (democrático o autocrático, absoluto o constitucional), no todo país tiene Constitución en el sentido jurídico de este término (...) la Constitución, en el sentido pleno de régimen constitucional efectivo, sólo tiene existencia real en la democracia ${ }^{16}$. Tradicionalmente se ha considerado que podía distinguirse en una Constitución una parte dogmática y una parte orgánica formando un todo. La parte dogmática recogería esos principios estructurales que son luego desarrollados por la parte orgánica. De esta manera la parte

${ }^{12}$ Otто, Ignacio De: Defensa de la Constitución... op. cit., pág. 16.

${ }^{13}$ Schmitт, Carl: Der Hüter der Verfamung, ed Dunker Humblot, Berlín, 1985, pág. 15.

${ }^{14}$ Alvarez Conde, Enrique, Tur Ausina, Rosario: Derecho Constitucional, 2. ${ }^{\text {a }}$ edición, 2012, pág. 87.

${ }^{15}$ Torres Del Moral, Antonio: Estado de Derecho y Democracia de Partidos, Universidad Complutense, Madrid, 1991, págs. 134 y 135.

${ }^{16}$ Idem pág. 141. 
dogmática es sustancialista y la orgánica procedimental. La segunda, nunca puede sobreponerse a la primera, al igual que no puede desviarse o contradecirse de la primera. Como advierte Pérez Serrano, debe considerarse que sólo la posición de supraordenación de la parte dogmática respecto de la parte orgánica expresa fielmente el control del poder político a favor de la libertad. Así la parte orgánica «sirve precisamente para asegurar ese sistema liberal y democrático de convivencia. La parte dogmática encierra lo decisivo y orientador; la organización estatal es un instrumento ${ }^{17}$. En el mismo sentido dice Torres del Moral, que «la parte orgánica ha estado siempre y debe estar en función de la parte dogmática. La parte orgánica es (...) garantía de la parte dogmática» ${ }^{18}$.

De lo aquí dicho cabe deducir que toda Constitución en el sentido que le hemos dado ha de descansar inexorablemente en el principio democrático y podemos afirmar que este es el único principio sustancial de la Constitución inmutable; otros principios estructurales (unidad, autonomía, autodeterminación, etc.) pueden variar de una Constitución a otra.

El principio democrático, con todos los subprincipios que de él se derivan (soberanía popular, división de poderes, garantía de derechos) ocupa una posición predominante sobre el resto, de manera que éstos últimos tienen como misión hacerlo realidad. Ello hace que nos planteemos la diferente disponibilidad de uno y otros, lo que nos lleva a distinguir entre lealtad constitucional, que lo es a todos los principios estructurales de la Norma Suprema de la lealtad democrática que lo es sólo al principio democrático, entendiendo que la democracia tiene una dimensión sustantiva y una dimensión procedimental. Esta última exige que cualquier cambio en la Constitución se haga por los mecanismos establecidos, la primera que medios y fin sean democráticos. Lo deja claro el TEDH en diversas sentencias, entre otras en la STEDH Partido de la Prosperidad c. Turquía, de 31 de julio de 2001:

«Un partido puede hacer campaña a favor de un cambio de la legislación o de las estructuras legales o constitucionales del Estado con dos condiciones: (1) los medios utilizados a ese efecto han de ser legales y democráticos desde cualquier punto de vista; (2) el cambio propuesto ha de ser compatible con los principios democráticos» (párf. 46).

${ }^{17}$ Pérez Serrano, Nicolás: Tratado de Derecho Constitucional, Civitas, Madrid, 1976, pág. 458.

${ }^{18}$ Torres del Moral, Antonio: Estado de Derecho... op. cit. pág. 149. 
De ahí que, por ejemplo, en la STEDH Partido Socialista Turco c. Turquía, de 25 de mayo de 1998, que abordaba la polémica cuestión del derecho a la autodeterminación del pueblo kurdo que resquebrajaba el principio de unidad nacional, uno de los principios estructurales de la Constitución turca inmodificables, afirmará ante su ilegalización que:

«Para el Tribunal, el hecho de que un proyecto político sea incompatible con los principios y estructuras actuales del Estado turco, no lo convierte en incompatible con las reglas democráticas. Pertenece a la esencia de la democracia permitir la proposición y discusión de proyectos políticos diversos, incluso los que cuestionan el modo de organización actual en un Estado, siempre y cuando los mismos no supongan un ataque a la democracia» (párf. 47) ${ }^{19}$.

¿Qué puede deducirse de la jurisprudencia del TEDH? En mi opinión que todos los principios estructurales que recoge una constitu-

${ }^{19}$ Ello no obstante, hay que advertir que el TEDH se muestra excesivamente cauteloso al intentar justificar la inclusión del derecho a la autodeterminación en el programa político del Partido Socialista al interpretar que lo que se pretendía con ello no era una separación de una parte del territorio sino la constitución de una federación:

«es cierto que aparece la cuestión de la autodeterminación de la «nación kurda»y de su derecho a «separarse». Ello no obstante, leído en su contexto, las declaraciones que contienen estos términos no incitaban a la separación con Turquía sino que más bien pretendían subrayar que la federación propuesta no podría realizarse sin el libre consentimiento de los kurdos, que debería expresarse por medio de un referéndum» (Párf. 47).

Esta declaración merece ser criticada pues la función del TEDH se ha de limitar a constatar que el proyecto de un partido político respeta los principios democráticos, y no sustituir la voluntad de un partido erigiéndose en interprete de su programa político: independencia o federación son proyectos igual de legítimos siempre que se defiendan por la vía democrática. Con dicha declaración arroja sombras sobre el derecho a la autodeterminación ¿qué hubiese sucedido si del contexto se desprendiera que lo pretendido era la independencia? La justificación es innecesaria salvo que la respuesta a esta pregunta supusiera no amparar dicha propuesta. Posiblemente consciente de ello, la desafortunada justificación desaparece poco después. En la STEDH Partido de la Libertad y de la Democracia de 8 de diciembre de 1999 simplemente se limita a afirmar, sin mayores consideraciones, que puede defenderse cualquier proyecto político, y la autodeterminación no es una excepción, siempre que se haga respetando las reglas del juego democrático:

«Es cierto que aparece la cuestión de la autodeterminación del pueblo kurdo. Para el Tribunal, el hecho de que un proyecto político sea incompatible con los principios y estructuras actuales del Estado turco, no lo convierte en incompatible con las reglas democráticas. Pertenece a la esencia de la democracia permitir la proposición y discusión de proyectos políticos diversos, incluso los que cuestionan el modo de organización actual de un Estado, siempre y cuando los mismos no supongan un ataque a la democracia misma» (Párf. 34).

Ello queda ratificado en la STEDH Aksoy de 10 de octubre de 2000 (Párf. 78) que asume palabra por palabra el párrafo anterior y, en cambio, no hace referencia alguna al párrafo aquí criticado de la STEDH Partido Socialista Turco. 
ción pueden ser objeto de debate y modificación salvo el principio democrático que por ello se sitúa en una posición de superioridad respecto a los demás. Ello es lógico pues el adjetivo que acompaña indefectiblemente a una Constitución es el de democrática. Cualquier otro principio no sirve para calificar a la Norma Suprema. Mantiene Aragón Reyes que también el principio democrático es disponible pues sólo existe una autolimitación procedimental pero no material del poder soberano por lo que «el pueblo tiene que conservar la libertad de decidir jurídicamente su propio destino.» ${ }^{20}$ "Ahí radica, precisamente, la grandeza de nuestra Constitución: en que ella misma facilita los medios jurídicos para su radical mutación: Y allí radica también la grandeza de nuestra democracia: en que permite a sus enemigos destruirla, pero eso sí, por procedimientos democráticos ${ }^{21}$.

Yo no me atrevería a tildar de grandeza permitir que mutemos a un pueblo de asesinos genocidas, por ejemplo. Veo en ello más bien una insensatez, siendo comedido en el calificativo. La República de Weimar no ha pasado justamente a la historia por su grandeza, pues nadie la ve en haber permitido una noche de los cristales rotos ni haber dejado paso a los genocidas que asesinaron a más de seis millones de judíos, a cientos de miles de otras etnias, y haber provocado una guerra que se saldó con más de sesenta millones de muertos, por más que democráticamente se les diera el poder a los dirigentes nazis perpetradores de tales grandezas. El profesor Aragón Reyes recurre, en último término, a una justificación metajurídica, sociológica para reforzar esta postura: los límites materiales significan la obligación de quedar sometidos a la voluntad de las generaciones del presente, con lo cual el Estado constitucional no sería del todo democrático, o que la democracia impone a esas generaciones "la triste obligación» 22 de expresar su voluntad en el marco de la norma, con lo cual el Estado democrático perdería su completa condición de Estado de Derecho, es decir, de Estado Constitucional.

No veo que sentar las bases para que las generaciones futuras no queden esclavizadas y puedan siempre desenvolverse en libertad sea triste, más que nada porque toda generación, como ha reconocido hasta el propio Tribunal de Estrasburgo, caso Ahmed, de 2 de septiembre de 1988, tiene el derecho de vivir en democracia y todo poder político la obligación de hacerlo posible y, añado yo, toda generación tiene la obligación de transmitir el legado de vivir en libertad a la siguiente, de tal suerte que si una de ellas la pretendiera hurtar a las

\footnotetext{
${ }^{20}$ Aragón Reyes, Manuel: Constitución y Democracia, Tecnos, pág. 35.

${ }^{21}$ ldem, pág. 49

${ }^{22}$ La cursiva es mía.
} 
futuras merecería ser tachada de desleal y traidora para con ellas. Elías Díaz, recurriendo también al argumento del pueblo y de las futuras generaciones, afirma que éste no puede destruir libremente la libertad porque «un pueblo es algo efectivamente en cambio, en constante cambio, donde nuevos miembros, nuevos hombres y mujeres, se suman continuamente incorporándose al colectivo anterior. Consecuentemente, la soberanía popular no es, por tanto, algo que se exprese sólo en un acto único sino que es algo que, en rigor, habría y hay que estar ejerciendo continuamente ${ }^{23}$ (...) y es que no corresponde ni puede atribuirse a ningún cuerpo electoral concreto enajenar en un momento dado y para siempre no ya la propia libertad sino también la de aquellos que (menores de edad o, incluso, no nacidos) no han podido, por tanto, participar en tal decisión y que, sin embargo, se encontrarían un día privados por sus mayores - y además bajo alegatos democráticos - de su libertad y de los derechos fundamentales que de ella derivan. Exigencia de la soberanía popular, de la legitimación democrática y de la propia regla de la mayoría sería pues, en esa circunstancia, la de consultar continuamente a los nuevos ciudadanos sobre el refrendo o no de tal anterior enajenación ${ }^{24}$.

En esa postura se posicionaba ya Peces Barba en 1978 en el debate en el seno de la Comisión de Asuntos Constitucionales y Libertades Públicas del Congreso de los Diputados en la que se debatía el anteproyecto de constitución: «Es un axioma que ningún demócrata puede negar, la afirmación de que ninguna generación puede comprometer la voluntad de las generaciones sucesivas. Nosotros agregaríamos, se debe incluso facilitar la libre determinación de las generaciones futuras» ${ }^{25}$ Indudablemente, si se enajena el derecho a vivir en democracia, las generaciones futuras no serán dueñas de su propio destino. $\mathrm{Y}$ es que una generación disfruta del derecho a vivir en democracia pero no a título de propiedad ya que tiene la obligación de transmitirlo a las generaciones sucesivas. Afirma Cotarelo que «la democracia es un bien en sí mismo; quien pretenda transformarla en otra cosa, cae fuera de la legalidad. El régimen democrático, por tanto, es inamovible» ${ }^{26}$ En definitiva, entre las cualidades de este derecho no se encuentra el ius abutendi. Este derecho tiene, por así decirlo, una

${ }^{23}$ Advierte este autor que con ello no está diciendo que desaparezca la democracia representativa.

${ }^{24}$ Díaz, Elías: De la maldad estatal y la soberanía popular, Debate, Madrid, 1984, págs. 66 y ss.

${ }^{25}$ Constitución Española, Trabajos Parlamentarios. Volumen I. Cortes Generales, 1980, 2. ${ }^{\text {a }}$ edición 1989, pág. 771.

${ }^{26}$ Cotarelo, Ramón: Los partidos políticos, Sistema, 1985, reimpresión 1996, pág. 168 . 
función social, que impide que la generación presente lo destruya. Se es depositario, no propietario del mismo. Como señalan Jorge de Esteban y López Guerra, en primer lugar el pluralismo político es un valor superior, debe reconocerse la posibilidad de gobernar a cualquier tendencia política que gane unas elecciones. Pero, en segundo lugar, la victoria de cualquier partido no puede implicar en su actuación posterior una negación ni siquiera una reducción del pluralismo político que pudiera desembocar en una situación de partido único.

En tal caso, se trataría automáticamente de una abolición legal de la norma fundamental27. Acertadamente advierte Pérez Luño que los valores son los criterios básicos para enjuiciar las acciones, ordenar la convivencia y establecer los fines. De ahí que supongan el sistema de preferencias expresadas en el proceso constituyente como prioritarias y fundamentadoras de la convivencia colectiva. Y entre las dimensiones que poseen se encuentra la de ser orientadoras del orden jurídicopolítico hacia unas metas o fines predeterminados que "hacen ilegitima cualquier disposición normativa que persiga fines distintos o que obstaculice la consecución de aquellos enunciados en el sistema axiológico constitucional $»^{28}$, para añadir que del artículo 10.1. CE en conexión con el 9.2. CE se impone una interpretación de los derechos fundamentales que los contemple no sólo como esferas subjetivas de libertad sino como elementos constitutivos de un sistema unitario de libertades patrimonio común de los ciudadanos, individual y colectivamente (STC de 14 de julio de 1981) «cuya extensión y eficacia máxima aparecen como la irrenunciable meta a alcanzar». ${ }^{29}$ El propio Tribunal de Estrasburgo ha sido tajante al respecto al afirmar en la STEDH Partido de la Prosperidad, de 31 de julio de 2001, que: «no existe democracia cuando la población de un Estado, aunque sea de forma mayoritaria, renuncia a sus poderes Legislativo y Judicial en provecho de un ente que no es responsable ante el pueblo que ella gobierna» (párf. 43).

Entre los derechos de tercera generación, basados en el principio de solidaridad, Peces-Barba identifica al derecho a un medioambiente sano, al derecho al desarrollo y al derecho a la paz. ${ }^{30}$ Vasak también

${ }^{27}$ La cursiva es mía. Esteban, Jorge De y LóPEz GuERRA, Luis: Los partidos politicos en la España actual, Planeta, Barcelona, 1962, pág. 195.

${ }^{28}$ La cursiva es mía. Pérez LuÑo Antonio E: Derechos humanos Estado de Derecho y Constitución. Tecnos, Madrid, 1964 pág. 268.

${ }^{29}$ La cursiva es mía. Idem pág. 316.

30 Peces-Barba Martínez, Gregorio 2. Curso de derechos fundamentales, Universidad Carlos III, 1995, págs. 157 y ss. 
habla del derecho a la paz. ${ }^{31}$ Este derecho a la paz está indefectiblemente unido al derecho a vivir en democracia que debería ser considerado también un derecho de tercera generación basado en la solidaridad no solo para nuestros semejantes sino también para con las generaciones futuras y cuya naturaleza, como el resto de derechos de esta generación (el ejemplo más claro es el derecho a un medioambiente sano) es la de derecho-deber: derecho a disfrutarlo y deber de conservarlo, a fin de transmitirlo, en las mismas condiciones o, incluso, mejorado a la siguiente generación.

Distingue Sartori entre el ideal democrático sin un sistema democrático y el ideal democrático en el marco de una democracia. En el primero, «dicho ideal desempeña el papel de adversario; su propósito predominante es la negación, el derrocamiento del sistema político al que se enfrenta. En un sistema democrático pretender el principio democrático en su expresión pura y máxima que postula «todo el poder para el pueblo» comienza a operar en sentido inverso, destructivo y no constructivamente. Alcanzada la victoria del lema «todo el poder para el pueblo» se produce ya el efecto de limitar el poder; su efecto real es la afirmación de un principio absolutista. Una maximización del ideal que desdeña y rechaza como impedimentos las estructuras intermedias que se encargan del ejercicio sólo puede generar, como tal, un poder absoluto en nombre del pueblo. Con lo que el ideal, al final, destruye a su criatura. Para evitarlo, concluye el profesor italiano, el principio "todo el poder para el pueblo» debe modificarse a medida que se desarrolla y convertirse en el principio todo el poder para nadie. ${ }^{32}$. Por tanto, el ideal democrático, alcanzada la democracia ha de ser abandonado so pena de que se convierta en una especie de Dios Cronos que devora a sus hijos. Una democracia para evitar su autodestrucción debe abandonar esas posturas ideales maximalistas y descender al mundo real. Y en ese mundo real, imperfecto, próximo a la caverna platónica, el principio democrático no es absoluto ni puede disponerse al antojo del soberano de turno, que hoy en día no es tanto el pueblo, como los partidos políticos, los nuevos príncipes como los define Gramsci. ${ }^{33}$

Centrémonos, en el principio democrático y en la lealtad democrática, en el sentido dado por el TEDH: que cualquier cambio ha de ser hecho por métodos democráticos que supone que son los recogidos

${ }^{31}$ VASAK, Karel: «Le droit international des droits de l'homme», Revue des droits de l'homme, vol I, Redove, París, 1972, pág. 45.

${ }^{32}$ SARTORI, Giovanni: Teoría de la Democracia, Vol 1, Alianza, 1987, págs. 98 y ss.

33 GRAMSCI, Antonio: "Note nil Machiavelli sulla política e sullo stato moderno», Quaderni del carcere, núm.4, Torino 1974, pág. 5. 
en el ordenamiento jurídico democrático, y que dicho cambio sea democrático. Coincido con este planteamiento, que suscita la duda de si un fin democrático (la independencia y la creación de un nuevo estado democrático) pretende ser alcanzado por un medio democrático (un referéndum) pero si ni tal fin ni tal medio están recogidos en el ordenamiento jurídico, ¿es democrático intentarlo al margen de la ley, teniendo en cuenta que el principio democrático exige, tal como se recoge en el artículo 9.1 CE que los poderes públicos y los ciudadanos están sujetos a la Constitución y al resto del ordenamiento jurídico? Y me estoy refiriendo en concreto al llamado proceso de desconexión iniciado unilateralmente por las instituciones catalanas. ¿Es leal o desleal con la Constitución y/o con la democracia intentar un cambio democrático por un método democrático pero no previsto por el ordenamiento jurídico? Dejo aquí apuntada la cuestión que no puedo abordar en este trabajo por motivos de espacio.

Existe controversia si en España los cargos representativos asumen un deber de lealtad constitucional, en el sentido de una adhesión positiva, de defensa activa de los postulados constitucionales, como sucede, por ejemplo en Alemania. En la República Federal Alemana, tras la dramática experiencia de que la República de Weimar permitiera al nacional-socialismo hacerse con el poder utilizando métodos democráticos, con las devastadoras consecuencias que ello comportó, se instauró la llamada democracia militante (die streitbare Demokratie) en la que además de excluir de la reforma determinadas partes de la Constitución y de prohibir a los partidos políticos la defensa de proyectos políticos incompatibles con el régimen democrático (Parteiverbot), se exigía a los cargos públicos un deber de lealtad política a la Constitución (die politische treuepflicht). Este deber de lealtad había sido fijado por el Tribunal Constitucional Alemán en una sentencia de 22 de mayo de 1975 y comprendía la obligación de todo cargo político y funcionario de separarse de forma inequívoca de los grupos que atacaran y difamaran al Estado y al régimen constitucional existente. El Tribunal Europeo de Derechos Humanos avaló tal exigencia en la sentencia Vogt c. Alemania, de 26 de septiembre de 1995, afirmando que «el Tribunal parte de que un Estado democrático tiene derecho a exigir de sus funcionarios que sean leales con los principios democráticos sobre los que se apoya» (Párf. 59).

En nuestro ordenamiento la cuestión se planteó con ocasión de la introducción en el artículo 20 del Reglamento del Congreso, en los artículos 11 y 12 del Reglamento del Senado y en el artículo 108.8 de la LOREG, de la exigencia al diputado o senador electo de prestar promesa o juramento de acatar la Constitución para adquirir la con- 
dición de diputado o senador. A la luz de estos preceptos, ¿Asumen nuestros cargos representativos una obligación similar a los cargos alemanes?, la respuesta, que ya adelantamos es negativa, la dio nuestro Tribunal Constitucional en su sentencia 101/1983, de 18 de noviembre. Hay que tener en cuenta que no tienen nada que ver las causas que motivaron la introducción de dicha obligación en Alemania y en España. El objetivo en Alemania era no repetir los errores del pasado y que un partido por métodos democráticos acabara con el orden constitucional; en España fue impedir que los diputados de Herri Batasuna disfrutasen de los derechos y prerrogativas parlamentarias, especialmente de la inmunidad, sin integrarse en la Cámara ${ }^{34}$.

Dicho requisito fue recurrido por posible vulneración del derecho a la libertad religiosa e ideológica (artículo $16 \mathrm{CE}$ ) conjuntamente con el derecho a acceder y desempeñar cargos públicos (artículo $23 \mathrm{CE}$ ). Niega el Tribunal Constitucional en la sentencia citada tal vulneración. En su análisis distingue entre el deber de acatamiento a la Constitución que deriva directamente de ésta y la exigencia de una promesa o juramento expreso de dicho acatamiento que no deriva directamente de la Constitución sino de los Reglamentos del Congreso y del Senado y de la LOREG. En tal sentido, señala que con ello «se limita a formalizar el deber positivo de acatamiento que contiene la Constitución, de la que deriva directamente como un requisito, al ser inherente al cargo, el deber de que se trata» (FJ 3), distinguiéndolo del deber de acatamiento general negativo que tiene todo ciudadano, consistente únicamente en abstenerse de cualquier actuación que vulnere el texto constitucional. ¿En qué consiste, pues, ese deber positivo de acatamiento impuesto a los cargos públicos? Dicho deber, dirá el Alto Tribunal, ha de ser entendido como «respeto a la Constitución, lo que no supone necesariamente una adhesión ideológica ni una conformidad a su total contenido, dado que también se respeta a la $\mathrm{CE}$ en el supuesto extremo de que se pretenda su modificación por el cauce establecido en los artículos 166 y ss. de la Norma Fundamental» (FJ 3). En la STC 122/1983, de 16 de diciembre, pondrá de manifiesto expresamente que «la fidelidad a la Constitución puede entenderse el compromiso de aceptar las reglas del juego político y del orden jurídico existente en tanto existe y a intentar su transformación por medios legales. La fidelidad de esta línea interpretativa no entra-

${ }^{34}$ Esfuerzo inútil, como puso de manifiesto Álvarez Conde, Enrique, Curso de Derecho Constitucional, Vol. II, Tecnos, edición 2000, pág. 93, pues este sistema no ponía fin al problema ya que tras cumplir con dicho requisito nada obligaba al diputado a asistir a las sesiones con lo que podía beneficiarse de aquellos sin mayor esfuerzo. 
ña una prohibición de representar y de perseguir ideales políticos diversos a los encarnados por la Constitución... siempre que se respeten aquellas reglas de juego» (FJ 5).

Ha lugar, por tanto, a distinguir entre el deber de acatamiento a la Constitución, que el Alto Tribunal hace derivar directamente de la Constitución, del acto concreto de promesa o juramento de acatamiento que según éste, es de configuración legal pues la Constitución no lo exige, aunque tampoco lo niega. Así se advierte en la STC 119/1990, de 21 de julio. Señala al respecto Díaz Revoiro que «ha de observarse que la exigencia de un acto formal de acatamiento añade algo más al propio deber de sujeción a la Constitución, pues (...) puede existir desde ciertas posturas una objeción al propio acto formal de jurar o prometer, mientras que la sujeción a la Constitución es una situación en la que se encuentran los ciudadanos y los titulares de los poderes públicos» y haciéndose eco del sentir de la doctrina, añade que existe en la argumentación del Tribunal una cierta confusión entre el deber de acatamiento y su manifestación formal, pues, partiendo de las premisas -ciertas- de que la Constitución no permite obtener un resultado por ella prohibido, y de que la Constitución prohíbe que los titulares de los poderes públicos accedan a sus cargos sin el deber de actuar con sujeción a la misma, llega a la conclusión, algo más que dudosa, de que el artículo $23 \mathrm{CE}$ no comprende el derecho a participar en los asuntos públicos por medio de representantes «que no acaten formalmente la Constitución ${ }^{35}$. En definitiva, el deber impuesto en los Reglamentos del Congreso y del Senado no aporta nada sustancial, no aporta una mayor exigencia de la que la Constitución exige a los cargos públicos, por lo que es un precepto materialmente inútil ${ }^{36}$.

Cabe plantearse si podría ser otra la lectura que aproximase ese deber de fidelidad al deber de lealtad que se exige a los cargos públicos en Alemania. El Tribunal Constitucional español, recordemos, dice textualmente que este deber no exige una adhesión ideológica ni

${ }^{35}$ DíAz Revoiro, Francisco Javier: «El acatamiento a la Constitución y el acceso de cargos representativos», Revista de las Cortes Generales, núm. 28, 1993, pág. 129.

${ }^{36}$ En la XI Legislatura ante la pregunta «¿juráis o prometéis acatar la Constitución?» algunos diputados o senadores utilizaron fórmulas problemáticas porque introducían una condición resolutoria: «Sí, lo prometo por imperativo legal, en espera de la constitución de la república catalana» (Diario de Sesiones del Senado, núm. 1, 13 de enero de 2016, págs. 1 y ss.). Es decir, que de producirse dicha eventualidad darían por extinguido el deber de acatamiento a la Constitución. El Tribunal Constitucional exige que la promesa o juramento no sea sometido a condición alguna por lo que entiendo que la fórmula no fue válida y que quien la utilizó no debería haber adquirido la condición plena de senador o diputado. 
una conformidad a su total contenido ${ }^{37}$. ¿Abre esta expresión a que determinadas partes de la Constitución sí que exigirían ese deber de lealtad «a la alemana», lo que nos acercaría a la posibilidad de considerar la nuestra una democracia militante? Es esta última cuestión, la de si la nuestra es o no una democracia militante, controversia que ha suscitado gran debate en nuestra doctrina. De Otto negó tal posibili$\mathrm{dad}^{38}$. En el mismo sentido se manifiesta nuestro Tribunal Constitucional en su sentencia 48/2003, de 12 de marzo al afirmar que en nuestro ordenamiento no tiene cabida un modelo de «democracia militante en el sentido que (el Gobierno Vasco) le confiere, esto es un modelo que imponga no ya un respeto, sino la adhesión positiva al ordenamiento y, en primer lugar, a la Constitución (...) falta para ello el presupuesto inexcusable de la inexistencia de un núcleo normativo inaccesible a los procedimientos de reforma constitucional». El profesor De Otto niega tal posibilidad a partir de una interpretación sistemática del artículo 9.1 CE y de la ausencia de límites a la reforma constitucional.

A partir de dicho precepto no es posible el establecimiento de mecanismos de defensa constitucional no previstos en la propia Carta Magna, toda vez que la exigencia derivada del precepto de referencia sería igual para ciudadanos y poderes públicos, igualdad que se vería quebrada al prohibir a los primeros la persecución de un fin que el título X de aquella considera lícito para la reforma constitucional; es decir para el poder constituyente constituido. Una vez admitido que el artículo 9.1 no establece un principio de sujeción al orden constitucional sino al derecho constitucional positivo, afirmar que el artículo 6 supone admitir que a los partidos se les exige más que a los ciudadanos y que a los propios poderes públicos, es absurdo. ${ }^{39}$ Hay que

${ }^{37}$ La cursiva es nuestra.

${ }^{38}$ OtTo, De, Ignacio: Defensa de la Constitución y partidos políticos, Centro de Estudios Constitucionales, 1985. En el mismo sentido JimÉnEz CAMPO, Javier: «la intervención estatal del pluralismo», Revista Española de Derecho Constitucional núm. 1, 1981, págs. 172 y ss. En sentido afirmativo se posicionan, entre otros, SANTAMARÍA PASTOR, Juan Alonso: «Comentario al artículo 6. ${ }^{\circ}$ de la Constitución» en GARRIDO FALLA, Fernando (ed.): Comentarios a la Constitución, Madrid 1985, págs. 95 y 96; ALzAGa ViLlamil, Oscar: La Constitución Española de 1978, Madrid, 1978, pág. 121, y ToRRES DEl Moral, Antonio: «Democracia militante», Derecho Constitucional para el siglo XXI, Actas de VIII Congreso Iberoamericano de Derecho Constitucional, Aranzadi 2006, págs. 2009 y ss; Tajadura Tejada, Javier: Partidos Políticos y Constitución, Civitas, 2003, y Álvarez Conde, Enrique y Catalá Bas, Alexandre H: El Derecho de Partidos, Colex, 2. ${ }^{a}$ edición 2013 págs. 139 y ss.

${ }^{39}$ De OtTo, Ignacio: Defensa de la Constitución... op. cit. pág. 21, 42, 47 y 48 . Defiende esta tesis Blanco Valdés Roberto L.: Los partidos politicos, Tecnos, 1990, págs. 139 y 140. El argumento del profesor De Отто de que el artículo 9.1. CE impone los poderes públicos y a los particulares la misma [la cursiva es mía] sujeción a la Cons- 
advertir, sin embargo, que el propio Tribunal Constitucional en su sentencia 119/1990 afirma que «no bastaría con emplear la fórmula ritual, sino emplearla, además, sin acompañarla de cláusulas o expresiones que de una u otra forma, vacíen, limiten o condicionen su sentido propio» (FJ 4), es decir, que ese ritual formal de acatar la Constitución tiene un cierto contenido sustancial. Sucede, ello no obstante, que las palabras del Alto Tribunal pecan de ambiguas, genéricas o excesivamente abiertas. ¿Qué entiende por cláusulas o expresiones con tales efectos? De acuerdo con ello, podría no admitirse un juramento o promesa acompañado de una defensa del nacionalsocialismo, del segregacionismo racial, de la esclavitud o de cualquier otro tipo de discurso del odio. En todo caso, es indudable que con las palabras del Alto Tribunal ese deber de lealtad trasciende lo meramente procedimental de respetar las reglas de juego para adentrarse en la exigencia de respetar un cierto mínimo sustancial. Lo que le convierte, de ser así, en un mecanismo de lealtad al principio democrático en esa dimensión.

El profesor Álvarez Álvarez distingue, como hemos visto, entre un deber de sujeción que lo es a toda la Constitución y un deber de lealtad que es a los principios estructurales de ésta. No puede asimilarse revisión total a elaboración de una nueva constitución que le está vedada al poder constituyente constituido. Una cosa es reformar un edificio que supone hacer todos los cambios que se desean pero manteniendo los pilares maestros y otra es derribarlo y construir uno nuevo. En el primer caso estaríamos ante una constitución reformada, en el segundo ante una nueva constitución cuya elaboración habría sido hurtada al poder constituyente. Lo que no dejaría de ser un acto de deslealtad del poder constituyente constituido. Indudablemente los poderes públicos han de defender activamente la Constitución pues han de cumplirla y hacerla cumplir. Es, en principio, un sinsentido pensar que una institución democrática trabaja para derrumbar la Constitución. Ello no obstante, el llamado proceso de desconexión del Estado, liderado por el Parlament de Catalunya, abre el debate sobre tal posibilidad. Señala el Tribunal Constitucional que el deber de respeto o lealtad a la Constitución no es el mismo para los ciudadanos (debe ser negativo) que para los poderes públicos (debe ser positivo). ¿Y qué sucede con los partidos políticos, para el nuevo

titución no parece ajustarse a lo mantenido por el Tribunal Constitucional ni con lo dicho por el mismo profesor en páginas anteriores de la misma obra cuando afirma que dicho precepto impone un deber de obediencia al derecho pero que «tal deber no puede de ningún modo ser el mismo para los ciudadanos que para los poderes públicos» [ldem, pág. 26] 
príncipe como los denomina Gramsci? ¿Se les puede exigir más que a un ciudadano? Los partidos políticos son entidades privadas pero, no olvidemos, con unos cometidos que le asigna la Constitución que no atribuye a las personas individuales. Cometidos que le hacen ocupar la centralidad del sistema, por más que nuestro Tribunal Constitucional intente esconder, minimizar o diluir esta situación anclándose en los postulados clásicos de la representación. Como dejan claro los magistrados discrepantes en su voto particular en la STC 10/1983, de 21 de febrero, «los partidos políticos, aun no siendo poderes públicos, tampoco pueden calificarse de simples organizaciones privadas y se sitúan en la zona gris entre lo público y lo privado (...) no siendo poderes públicos ejercen, sin embargo, funciones públicas (...) porque expresamente lo dice el citado artículo $6 .^{\circ}$ de la Constitución». Advierte acertadamente Blanco Valdés, siendo esta postura más consecuente, más coherente desde la perspectiva de la Constitución «material», "con las realidades caracterizadoras del moderno estado democrático de partidos» por lo que «la cuestión no debe consistir en dilucidar la naturaleza jurídica de los partidos (...) sino en determinar la naturaleza de las funciones que tienen atribuidas los partidos en el Estado democrático contemporáneo ${ }^{40}$.

Si esto es así, a los partidos se les puede exigir un mayor grado de vinculación con la Constitución que a un simple particular. Es también un sinsentido dar la espalda a la realidad. Se quiera o no, los partidos han dejado de ser meros instrumentos o intermediarios. El electorado les vota a ellos y no a los integrantes de la lista. Ahora bien, a los electos de esa lista se les puede exigir el mismo grado de compromiso o lealtad que a los partidos, como advierte Duverger, el electo le debe su elección al partido que lo selecciona y al elector que vota por lo que reciben un doble mandato. ${ }^{41}$ Además, el representante entra a formar parte del parlamento que no puede conspirar contra el orden constitucional. Establecido el orden constitucional en el sentido que Sartori le otorga, es decir, basado en el principio democráti$\mathrm{co}^{42}$, no hay marcha atrás si no es mediante una revolución, o un golpe de estado que incluso puede llegar a contar con el apoyo mayoritario de la población. Pero esto no sucede de un día para otro. Un estado no se acuesta democrático y se levanta totalitario. Esta metamorfosis es una consecuencia de una transformación que se prolonga en el tiempo, como la primera célula cancerígena en un cuerpo, que

${ }^{40}$ Blanco Valdés Roberto L.: Los partidos... op. cit. pág. 154.

${ }^{41}$ Duverger, Maurice: Los partidos políticos, Fondo Cultural Económico, séptima reimpresión 1979, pág. 378.

${ }^{42}$ SARtori, Giovanni: Elementos de Teoría Política, Alianza, edición 2012, pág. 19. 
no se extirpa y se va extendiendo hasta devorarlo completamente. De lo que se trata es de evitar su propagación, si aun así no se frena, desgraciadamente y como sucede en la vida real, nada hay que hacer. La quimioterapia, la radioterapia y otros tratamientos son al cáncer lo que los mecanismos de defensa democrática a la democracia, y al igual que a nadie le gusta someterse a un tratamiento de este tipo pero lo hace para intentar salvarse, sucede lo mismo con una democracia. Como afirma Torres del Moral, no nos podemos quedar con un concepto formal de democracia desprovisto de contenido material «la democracia no se puede predicar sólo de la parte orgánica de la Constitución, dejando inerme la parte dogmática ${ }^{43}$.

La democracia está indisociablemente unida a unos valores, y como advierte Sartori, la exclusión de valores (Wertfheihert) afecta negativamente a la teoría de la democracia puede utilizarse para representar entidades antitéticas y dignificar prácticas opuestas ${ }^{44}$. En el mundo real, la existencia de un cáncer antidemocrático, ha de ser tenido en cuenta a la hora de formular cualquier teoría sobre si la democracia ha de ser militante o no. Al igual que ese mundo real nos debe hacer comprender que, desgraciadamente, si, a pesar de todo, el cáncer se sale con la suya no hay nada que hacer por más que desde un punto de vista teórico pueda decirse con Rousseau que es una contradicción que un acto de soberanía popular pueda tener por objeto su propia supresión.

Vayamos por partes. La Constitución española sí exige un deber positivo de acatamiento a los cargos públicos que va más allá de lo que se exige a los ciudadanos privados. La diferencia es que la Constitución alemana exige la defensa activa de determinadas partes de la Constitución, las que están fuera de la posibilidad de reforma, no de toda ella. Segundo, según el Tribunal Constitucional, nuestra Constitución permite la reforma total de la Constitución, por lo que al no excluir ninguna parte de una posible reforma no estamos ante el modelo alemán de democracia militante a lo que cabe hacer dos observaciones, a su vez. La primera: discrepo de la conclusión de que la reforma total de la Constitución sería incompatible con la existencia de una democracia militante. Excluir determinadas partes de la reforma es un mecanismo de defensa de la Constitución, no parte de su definición. Al hilo de esto, la segunda observación va en el sentido de que el propio Tribunal excluye que no tiene cabida un modelo de democracia militante a la alemana; a contrario sensu podría entenderse que

${ }^{43}$ Torres del Moral, Antonio: «Democracia militante....op. cit. pág. 219.

${ }^{44}$ SARTORI, Giovanni: Teoría de la Democracia, vól. I, Alianza, 1987, pág. 25. 
existen otros modelos de democracia militante distintos del alemán, conclusión que mantengo como a continuación expondré.

La jurisprudencia del Tribunal Constitucional ha sido asumida, por confusa, en un sentido erróneo por el Tribunal Supremo en su sentencia de 27 de marzo de 2003, en la que afirma que «nuestro sistema político responde a un régimen de libertad política prácticamente ilimitada, adquiriendo pleno sentido que nuestra Constitución no haya optado por un sistema de democracia militante sino por un sistema extremadamente tolerante a favor de todos los postulados políticos» planteamiento que hunde sus raíces en las sentencias del Tribunal Constitucional 20/1990, de 1 de marzo, 214/1991, de 11 de noviembre o 176/1995, de 11 de diciembre. Así, en esta última llega a afirmar que «es evidente que al resguardo de la libertad de opinión cabe cualquiera, por equivocada o peligrosa que pueda parecer al lector, incluso las que ataquen al sistema democrático. La Constitución -se ha dicho- protege también a quienes la niegan» (FJ 2).

¿Es evidente esto? ¿Es evidente que nuestra Constitución ampara a quien quiera imponer un régimen de apartheid, la esclavitud, la xenofobia o el racismo, el integrismo religioso, el antisemitismo o un régimen genocida? ¿Y los artículos 607 o 515 CP? No existen unas pretendidas constituciones democráticas neutrales. Ello es una contradictio in terminis. Una constitución democrática no se limita a fijar unas reglas de juego para acceder al poder, no es una norma meramente procedimental, sino que se sustenta en unos valores tales como la libertad y la igualdad, valores que normalmente aparecen reflejados en el articulado de la Carta Magna por lo que se normativizan y se irradian a toda la Constitución y al resto del ordenamiento jurídico. Peces-Barba inicia su conocida obra Los valores superiores con la siguiente declaración de principios: "Los valores superiores se sitúan en el umbral mismo de la Constitución, en ese artículo $1 .^{\circ}$, de suma importancia, que constituye, en mi opinión, la norma básica (...) son los cuatro faros que guían, explican e interpretan la voluntad del legislador constituyente y punto de partida de todo el resto del ordenamiento jurídico ${ }^{45}$.

El debate pues, ha de plantearse en otros términos que no son otros que si una constitución democrática ha de ser inerme; es decir,

${ }^{45}$ Peces-Barba Martínez, Gregorio: Los valores superiores, Tecnos, 1984, pág. 17. Señala en este sentido Elías Díaz que «todo sistema de legalidad (...) incorpora y realiza a través de sus normas un determinado sistema de legitimidad, un determinado sistema de valores e intereses (...) no hay, pues, una legalidad neutra y adiáfora». DíAZ, Elías: De la maldad estatal y la soberanía popular, Debate, 1984, pág. 27. 
que no adopta o permite adoptar medidas para protegerse de aquellos que quieren acabar con ella y, por ende, con el régimen democrático en cuya cúspide de su ordenamiento jurídico se encuentra o si, por el contrario, permite adoptar medidas para hacer frente a dicha eventualidad. Decisión que, en todo caso, compete al poder constituyente a la hora de elaborarla. En su momento, la Ley Fundamental de Bonn adoptó medidas de este tipo que se mantienen en la actualidad: la irreformabilidad de determinadas partes de la Constitución (la que hace referencia a la estructura federal del Estado, la relativa a que Alemania es un Estado de Derecho y la relativa a los derechos fundamentales) y la posibilidad de ilegalizar aquellos partidos que pretendían acabar con el régimen democrático. Estos mecanismos vistos en su conjunto exceden de lo que podría denominarse de lealtad democrática para convertirse en mecanismos de lealtad constitucional, pues si bien algunos están vinculados al principio democrático, otros, como la irreformabilidad de la estructura territorial del estado, se sitúan extra de dicho principio. Más próxima a lo que debería ser una democracia militante strictu sensu es la doctrina que ha consolidado el Tribunal Europeo de Derechos Humanos que considera que para que un proyecto político sea defendible en democracia ha de cumplir dos condiciones: que se haga por medios pacíficos y que el proyecto sea en sí democrático, pues la democracia es el único sistema político compatible con el Convenio Europeo de Derechos Humanos. Superados esos dos requisitos que definen el principio democrático, todo proyecto es defendible aunque ponga en jaque principios estructurales de la constitución de turno como el de la unidad nacional ${ }^{46}$.

Cierto es que el artículo $168 \mathrm{CE}$ permite la revisión total de la Constitución pero una reforma tal no puede confundirse por el arrumbamiento de los principios estructurales sobre los que se asienta y su sustitución por otros pues en ese caso estaríamos no ante una constitución reformada sino ante una nueva constitución, lo que es tarea no del poder constituyente constituido sino del poder constituyente. Como advierte Pedro de Vega, la lectura aislada del artículo 168.1 CE no nos puede llevar a la conclusión de que nuestro texto fundamental ha optado por un indeferentismo ideológico total. Semejante decisión implica olvidar que la revisión es fundamentalmente un procedimiento de defensa, no de subversión de la Constitución ${ }^{47}$.

${ }^{46}$ Vide, por todas, SSTEDH Partido Comunista Unificado c. Turquía, de 30 de enero de 1998 y Partido Socialista c. Turquía, de 25 de mayo de 1998.

${ }^{47}$ VEGA, Pedro de: «La reforma constitucional» en Estudios sobre el proyecto de Constitución, Madrid 1978, pág. 220. En el mismo sentido JiménEz CAMPO, Javier: "Algunos problemas de interpretación en torno al Título X de la Constitución», Revista del Departamento de Derecho Político, núm. 1980, pág. 87-88. 
Cualquier reforma, como recuerda Belda, ha de respetar el principio democrático ${ }^{48}$. Ya en 1985, Ignacio De Otto, que mantenía que nuestra Constitución no consagra una democracia militante, afirmaba que desde el punto de vista de la Teoría Constitucional democrática, la cuestión de si hay límites absolutos a la reforma tiene que responderse afirmativamente: «sin duda alguna hay un límite absoluto, uno al menos que consiste, para decirlo en términos concisos, en que la democracia no puede destruirse a sí misma por decisión democrática». ${ }^{49}$ Con toda humildad, y sin poderme extender por razones de espacio, no comparto la opinión del profesor Aragón Reyes de que «el artículo 168 de nuestra Constitución supone en rigor, la juridificación del poder constituyente ${ }^{50}$. Esto puede ser aceptado únicamente si identificamos revisión total a nueva constitución y si aceptamos que se ha producido una traslación del poder soberano desde el pueblo al órgano del artículo $168 \mathrm{CE}$.

Entiendo que lo recogido en dicho precepto es un poder constituyente constituido. El hecho de que el resultado final de la revisión total sea sometido a referéndum al verdadero soberano para su ratificación no convierte todo ese proceso en un verdadero proceso constituyente. Por otra parte, y como se deduce de lo mantenido con anterioridad, incluso el poder constituyente en el mundo real no es absoluto pues nunca dicho poder en un estado democrático podría aprobar, por ejemplo, una cláusula que permitiese la eliminación o esterilización de determinadas minorías étnicas o una política imperialista. ¿Podría el pueblo, poder constituyente, decidir soberanamente convertirse en genocida, esclavista, segregacionista o imperialista? Sin duda no, porque, en último término, esa decisión quedaría en nada por la presión o, incluso, la intervención de la Comunidad Internacional. ¿Alguien piensa que ello podría darse en nuestro país que forma parte de la Unión Europea, del Consejo de Europa y de la ONU? Hay, pues, que abandonar la idea de que el pueblo soberano tiene un poder tan absoluto como para traicionar el principio democrático en los términos que hemos puesto como ejemplos.

Queda la cuestión de quién pone el cascabel al gato. Hoy en día no existe un procedimiento para encauzar la actividad del poder consti-

${ }^{48}$ Belda PÉRez-Pedrero, Enrique: «Los límites a la reforma constitucional ante propuestas más propias de una revolución», Teoría y Realidad Constitucional, núm. 29, 2012, pág. 263.

${ }^{49}$ OtTo, Ignacio De: Defensa de la Constitución... op. cit. págs. 29 y 30. Vide en el mismo sentido Díaz, Elías: De la maldad Estatal y la soberanía popular, Debate, 1984, págs. 67 y 68 .

${ }^{50}$ ARAGón Reyes, Manuel: Constitución...., op. cit. pág. 49. 
tuyente, pues como poder absoluto se cuestiona si ello es posible ya que no puede quedar ligado a una legalidad anterior interna pero $¿ y$ externa? Nadie mantiene que España, como miembro de la Unión Europea, sea soberana para tomar cualquier tipo de decisión. Sea como fuere, el poder constituyente no disfruta de las cualidades de un dios: infinito, absoluto, omnicomprensivo, omnipotente...; y es que al igual que nadie puede bañarse dos veces en el mismo río, nunca puede activarse el mismo poder constituyente pues el pueblo es algo cambiante y dinámico, que fluye y se transforma no sólo con el paso de las generaciones sino día a día. Privar de ese poder al pueblo del futuro que es no ya el de la siguiente generación sino el del día siguiente al de haber tomado esa decisión me parece algo que el Derecho no puede soportar.

Es a ese principio a lo que debería quedar circunscrito el deber de lealtad, como deber de defensa, adhesión positiva y acción pedagógica, dejando fuera otros principios estructurales como pueden ser el de la unidad. Recordemos que el Tribunal Constitucional en la STC 101/1983 dice que el deber de acatamiento a la Constitución no supone «una adhesión ideológica ni una conformidad a su total contenido». Lo que a contrario sensu no descarta que sí pueda exigirse en relación con determinadas cláusulas que coincidirían con las que parte de la doctrina ha señalado como cláusulas de intangibilidad. Me estoy refiriendo a los artículos 1.1, 1.2 y 10.1 CE. Esas cláusulas deberían aparecer expresamente en el juramento o promesa de acatamiento anudadas a la obligación a que acabamos de hacer referencia ¿Qué otra cosa son sino pruebas de lealtad democrática la declaración que el artículo 6 LOREG exige a los cargos representativos de partidos ilegalizados para no desposeerlos del cargo $^{51}$ o el 9.2 LOPP que señala que un partido puede ser ilegalizado cuando persiga deteriorar o destruir el régimen de libertades o imposibilitar o eliminar el sistema democrático o el artículo $516 \mathrm{CP}$ que declara ilícitas aquellas asociaciones cuyo objetivo es el odio, la hostilidad, discriminación o violencia contra personas o grupos por razón de su ideología, religión, creencias, pertenencia a una etnia, raza, nación, sexo, orientación sexual, situación familiar, enfermedad o discapacidad? Si releemos la STC 122/1983, el Tribunal Constitucional circunscribe el deber de

${ }^{51}$ En este sentido, TORRES DEL MORAL propone incluir en el protocolo de la toma de posesión junto al juramento o promesa de acatamiento a la Constitución, la condena al terrorismo. TorRes DEL Moral, Antonio: «Requiem por...», op. cit. pág. 57. Pero ¿por qué circunscribir la fórmula al rechazo del terrorismo y no a otras causas que pueden dar lugar a la ilegalización de un partido, contenidas en el Código penal como el racismo o la xenofobia? Creo que la fórmula ha de ir en el sentido anteriormente apuntado. 
lealtad al respeto a las reglas del juego; pero ¿qué reglas del juego?, las únicas que se derivan de nuestra Constitución: las reglas de juego democráticas. Y éstas sólo son unas y sólo pueden ser sustituidas por sus antagónicas: las reglas de juego no democráticas. De aquí cabe deducir que respetar esas reglas de juego democrático en una constitución que no es meramente procedimental sino material, va más allá de acatar unas reglas para que existan unas elecciones competitivas cada cierto tiempo en las que se permita la libre concurrencia de diferentes partidos políticos para adentrarse en la concepción sustancial de la constitución que forma un continuum con su dimensión procedimental. Respetar las reglas de juego democrático supone no sólo alcanzar el poder por métodos democráticos sino, una vez logrado ese hito, seguir respetándolas, es decir, no intentar acabar entonces con el principio democrático. La STC 101/1983 señala que el respeto a dichas reglas abarca no intentar su modificación fuera de los cauces establecidos en los artículos 166 y ss CE. Pero, la revisión total de la Constitución no permite cambiar las reglas de juego democrático por unas reglas de juego no democrático. No creo que con el procedimiento previsto en el artículo $168 \mathrm{CE}$ pueda sustituirse la actual redacción del artículo $1 \mathrm{CE}$ por una en la que se diga que «España constituye una unidad de destino en lo universal» y que la separación de poderes quede sustituida por la unificación de todos los poderes en manos de un caudillo que sólo responde ante Dios y ante la Historia.

De lo anterior concluyo, si bien es cierto que de forma un tanto apresurada por razón de espacio, que ese deber de lealtad a la Constitución, lo que realmente ha de convertirse es en un deber de lealtad al principio democrático, a la democracia como régimen político en definitiva.

No se pueden establecer compartimentos estancos. Es un sinsentido exigir una lealtad procedimental pero no una sustancial. El medio, el procedimiento, sólo tiene sentido si se relaciona con el fin, con el proyecto, tal como hace el Tribunal de Estrasburgo. Todo ha de responder a la misma concepción del mundo. De ahí que no todo Estado con Derecho sea un Estado de Derecho, como afirma Garrorena González ${ }^{52}$ ni todo Estado que posee una «constitución» sea un Estado Constitucional tal como afirma Sartori ${ }^{53}$. Hoy en día no puede mantenerse la afirmación de Kelsen de que «si se reconoce en el Estado un orden jurídico, todo Estado es un Estado de Derecho» tachando de prejuicio insnaturalista los intentos de reducir dicha expresión

52 Garrorena GonZÁLez, Ángel: El Estado Español como Estado social y democrático de Derecho, Tecnos, 1984, pág. 158.

${ }^{53}$ SARTORI, Giovanni: Elementos de Teoría Política, Alianza, edición 2012, pág. 19. 
al «Estado que corresponda a las exigencias de la democracia y de la seguridad jurídica». ${ }^{54}$ Así Loewenstein distinguía entre constituciones garantistas, nominales y pseudoconstituciones. Las nominales son meramente organizativas. Sólo son auténticas constituciones las garantistas $^{55}$. Entrar a limitar las ideologías o proyectos que puedan defenderse en una democracia supone un peligro para el pluralismo político; ello es indudable pero como advierte Sartori, la indiferencia jurídica hacia los problemas declarados meta-jurídicos ha sido desastrosa en sus resultados. Cuando un problema político se despolitiza, las consecuencias efectivas de un ordenamiento jurídicamente «neutral» son y siguen siendo políticas; y ello beneficia a los demagogos y a los déspotas ${ }^{56}$.

\section{LA LEALTAD DE LOS CARGOS REPRESENTATIVOS EN LOS PARTIDOS POLÍTICOS}

La tan denostada democracia de partidos goza de excelente salud. La realidad es tozuda. Se habla de que los partidos tradicionales han entrado en crisis. No es este el lugar para analizar la cuestión, pero aceptemos como cierta esta afirmación. En España hemos asistido a grandes movilizaciones contra dichos partidos y aunque la tan repetida frase «no nos representáis» iba dirigida a los representantes políticos, especialmente a los líderes políticos, detrás de ella se escondía un ataque o crítica a los partidos políticos tradicionales en cuanto responsables de su designación. Dichas movilizaciones tales como las del 15-M, las que se oponían a los desahucios, etc. alumbraron a asociaciones y plataformas. Estas iniciativas populares, como advierte Offe, pueden ser muy bien asimiladas e integradas con facilidad por el sistema capitalista llegando a asumir el papel de partners mirados con simpatía por la administración por funcionar a nivel político como un "sistema de alarma preventivo» señalando con anticipación los posibles conflictos y los potenciales obstáculos al desarrollo, suministrando pues indicaciones sobre los puntos donde la administración

${ }^{54}$ KeLSEN, Hans: Valor y esencia ... op. cit. pág. 315. Aunque como recuerda PéRez LuÑo, Kelsen, en la segunda edición de su Reine Rechtslehre, no duda en señalar que por estado de derecho debe entenderse un cierto tipo de Estado: aquel que responde a las exigencias de la democracia y de la certeza del derecho. Pérez Luño, Antonio E: Derechos humanos.... op. cit. pág. 239.

${ }^{55}$ Loewenstein, Karl: Political Power and Governmental Process, University of Chicago Press, 1965, págs. 147 y ss.

${ }^{56}$ SARTORI, Giovanni: Elementos de... op. cit. pág. 26. 
debe aplicar su propia actividad. ${ }^{57} \mathrm{El}$ movimiento asociativo en el seno de la sociedad fue importante pero lo paradójico del caso es que dichas asociaciones han terminado metamorfoseándose en nuevos partidos políticos. Pone de relieve el mismo autor que todo movimiento social, como en su momento fueron Los Verdes, se enfrentan tarde o temprano a un dilema de desarrollo en el que «no pueden seguir siendo simplemente lo que ya son» ni tampoco pueden "pasar a ser un partido como los demás, sin una ruptura traumática de su identidad.» ${ }^{58}$ Dichos movimientos terminan por entrar en una fase de autorracionalización que les llevará un proceso de maduración y racionalización política ${ }^{59}$ lo que les lleva a abandonar en gran medida el espacio de política no institucional que les caracterizaba en el momento inicial. ${ }^{60}$

Y es que, en definitiva, en palabras de Von Beyme, «una organización partidista es siempre necesaria para los nuevos movimientos sociales que se enfrentan a los órdenes sociales establecidos.» ${ }^{61} \mathrm{Y}$ así vemos que junto a los partidos de siempre aparecen otros que irrumpen con fuerza en la arena política y que, mal que les pese, repiten estructuras y formas de los llamados tradicionales; por mucho que quieran aparentar nuevos modos de hacer política. Distingue Duverger dos clases de partidos: los partidos tradicionales, relativamente poco sensibles a las «variaciones cíclicas» y los partidos nuevos, que fundan en ellos su crecimiento o su caída. Los primeros, comunidades estables y estabilizadoras, desempeñarían un papel de amortiguadores políticos; los otros, comunidades ardientes y frágiles, amplificarían, por el contrario, los movimientos de opinión nacidos de los acontecimientos. ${ }^{62}$ Esos nuevos partidos van perdiendo paulatinamente su inicial empuje revolucionario y antisistema para convertirse en ese tránsito de forma también paulatina en leales al sistema. La realidad, como he dicho es tozuda, y lo que vemos son nuevos partidos con líderes asentados que manejan más o menos con guante de hierro estas nuevas organizaciones, que se rodean de los fieles y defenestran a los disidentes, que consultan a las bases con preguntas pre-

${ }^{57}$ OfFe, Claus: Iniciativas populares y reproducción de la fuerza del trabajo en el capitalismo tardío, Sistema, 1971, págs. 211 y ss.

${ }^{58}$ Offe, Claus: Partidos políticos y nuevos movimientos sociales, Sistema, 1992, pág. 247.

${ }^{59}$ Ibidem, pág. 259.

${ }^{60}$ Ibidem, págs. 173 y ss.

${ }^{61}$ Von Beyme, Klaus: Los partidos politicos en las democracias occidentales, Centro de investigaciones sociológicas, 1986, pág. 198.

${ }^{62}$ Duverger, Maurice: Los partidos politicos, Fondo de Cultura Económica, 1957, pág. 114. 
fabricadas para que la respuesta sea la que ellos desean oír, preguntas, por tanto, retóricas de las que de antemano se sabe la respuesta, que crean una burocracia partidista y un clientelismo, que al igual que hacen los tradicionales, varían su discurso antes y después de unas elecciones... Por lo tanto, pueden aparecer nuevos partidos políticos, los tradicionales no obtener los resultados de antaño, podemos ir, en definitiva, a un nuevo sistema de partidos pasando de un bipartidismo imperfecto a un multipartidismo moderado que puede introducir ciertas dosis de inestabilidad, pero, en definitiva, la democracia de partidos sigue gozando de buena salud, pues los partidos como intermediarios y canalizadores de la voluntad popular no han sido sustituidos por nuevos actores, y siguen reforzando su poder.

En los parlamentos medievales, con el mandato imperativo, y el tránsito hacia los parlamentos modernos en el que aquél es sustituido por el mandato representativo la relación entre elector-representante era más o menos directa hasta la aparición de un cuerpo intermedio, el partido político, que se interpone en esa relación primigenia. Nacido como medio, como instrumento, ha terminado por ocupar el eje central de las relaciones políticas de tal suerte que todo pivota a su alrededor. Como pone de relieve Kelsen, «la voluntad colectiva sólo puede consistir en la resultante o transacción de intereses divergentes, y la articulación del pueblo en partidos políticos significa propiamente la creación de condiciones orgánicas que hagan posible aquella transacción y permitan a la voluntad colectiva orientarse en una dirección equitativa ${ }^{63}$. Aparece una doble relación, la de elector-partido y la de diputado-partido ${ }^{64}$. Caamaño afirmará que el partido ha sustituido al representante. Los partidos devienen de este modo en el centro de dirección política del Estado ${ }^{65}$. En el mismo sentido dirá Torres del Moral, que se ha perdido la relación en el distrito entre representante y electorado. Ahora hay tres relaciones. Candidato/partido político; electores/partido político y electores/líder del partido político, adquiriendo en este último binomio las elecciones un claro tinte plebiscitario $^{66}$.

${ }^{63}$ Kelsen, Hans: Esencia y valor de la democracia, Labor, 1934, pág. 43.

${ }^{64}$ GaRRORENA GonZÁLEZ, Ấngel: «Apuntes para una revisión crítica de la teoría de la representación», en GARRORENA A. (ed.), El Parlamento y sus transformaciones actuales, Tecnos, 1990, págs. 46-49.

${ }^{65}$ CaAmaño Domínguez, Francisco: El mandato parlamentario, Publicaciones del Congreso de los Diputados, 1992.

${ }_{66}$ TORRES DEL Moral, Antonio: «Requiem por el mandato representativo, Revista de Derecho Político, núm. 81, 2011, pág. 53. En relación a esta última cuestión vide WEBER, Max: Economía y Sociedad, Fondo de cultura económica, 1969, pág. 1084 y Held, David: Modelos de democracia, Alianza, 1987, pág. 192. 
La teoría del mandato representativo tiene difícil encaje en la democracia de partidos. El propio Tribunal Constitucional es consciente de esta realidad. Si por un lado afirma en la STC 5/1983, de 4 de febrero que «el derecho a participar corresponde a los ciudadanos y no a los partidos, que los representantes elegidos lo son de los ciudadanos y no de los partidos y que la permanencia en el cargo no puede depender de la voluntad de los partidos sino de la expresada por los electores» por otra, destaca en la STC 32/1985, de 6 de marzo, que «la consagración constitucional de los partidos políticos como expresión de tal pluralismo, cauces para la formación y manifestación de la voluntad popular e instrumentos fundamentales para la participación política de los ciudadanos (art. 6), dotan de relevancia jurídica (y no solo política) a la adscripción política de los representantes».

En nuestro sistema actual, la ciudadanía se pregunta a quién pertenece el escaño ¿al electo, al partido político, al grupo parlamentario o municipal, al electorado? El votante se inclina por unas siglas y, en todo caso, por un líder pero no por unas personas cuyo nombre va emboscado en una lista que nadie se preocupa de leer más allá del segundo o tercer nombre, que son, en muchas ocasiones desconocidas para gran parte del electorado y que ni tan siquiera han sido puestos allí por las bases del partido sino por la élite del mismo. Lo advertía Kelsen ya en 1920: «en los casos de sistema electoral por listas [...] los electores no designan al diputado por su persona, sino que su voto significa un acto de adhesión a un partido determinado, de manera que el candidato obtiene su representación sólo en virtud de su filiación al partido del elector, siendo lógico que el diputado pierda su mandato tan pronto deje de pertenecer al partido que lo ha enviado al Parlamento ${ }^{67}$. Existe un divorcio entre realidad política y realidad jurídica y, como afirma Caamaño «mientras que política y sociológicamente son los partidos los auténticos titulares del mandato electoral, jurídicamente esa titularidad se atribuye intuitu personae al representante» ${ }^{68}$. Un divorcio entre realidad política y realidad jurídica. El escaño es del representante y el partido no puede hacer nada para arrebatárselo. Afirma De Vega, que «en el supuesto de confrontación entre diputado y partido es evidente que la lógica de la democracia partidista y el principio de proporcionalidad, tienen que ceder por

\footnotetext{
${ }^{67}$ Kelsen, Hans: Esencia..., op. cit. pág. 69.

${ }^{68}$ CaAmaño Domínguez, Francisco: «Mandato parlamentario y derechos fundamentales», Revista Española de Derecho Constitucional, núm. 36, 1992, pág. 129.
} 
obligación a la lógica del principio clásico de representación, por ser el único constitucionalmente regulado ${ }^{69}$.

El partido político es consciente de esta realidad y ejerce una «férrea disciplina castrense» sobre los cargos representativos ${ }^{70}$ de tal suerte que el representante queda anulado en su autonomía individual y es engullido en el grupo parlamentario o municipal dominado, a su vez, por el partido político. Es decir, el representante sufre una doble alienación: su individualidad o autonomía se disuelve en el seno del grupo político y del partido político. El partido, en definitiva, marca la estrategia a seguir, fija el sentido del voto, confecciona las listas, distribuye los cargos, etc. Lo que ha hecho que se hable de una auténtica tiranía de los partidos en la que el centro real del poder se ha desplazado y concentrado en sus órganos de dirección ${ }^{71}$. Se habla así de un nuevo mandato imperativo, el mandato de partido basado en la disciplina de voto que Sartori ve con buenos ojos al afirmar que ésta no supone, per se, una negación de la democracia dentro del partido, siempre y cuando se haya podido discutir y debatir antes de forma abierta en las estructuras del partido el posicionamiento a debate $^{72}$. La uniformidad del voto, dirá este autor, es un mal necesario pero sólo ella asegura la estabilidad del sistema. Sin embargo, la objeción o reparo a esta opinión la explicita el propio autor: «siempre y cuando se haya podido debatir antes de forma abierta ${ }^{73}$. Todo ello le lleva a afirmar a Leibholz que la democracia y el Estado de partidos (que sustituye a la verdadera democracia representativa) han introducido un cambio en la posición del diputado respecto al carácter libre o imperativo de su mandato ya que siendo elegido por su inclusión en

${ }^{69}$ De Vega, Pedro: «Significado constitucional de la representación política», Revista de Estudios Políticos, núm. 44, 1985, pág. 5.

${ }^{70}$ TORRES DEL Moral, Antonio: «La crisis del mandato representativo en el Estado de Derecho», Revista de Derecho Político, núm. 14, 1982, pág. 17.

${ }^{71}$ En este sentido, Marinini, G., Miti e Realtà della Democrazia, Milano, Communita, 1958.

${ }^{72}$ SARTORI, Giovanni: Ingeniería Constitucional comparada, Fondo de Cultura Económica, 1994, pág. 210. En el mismo sentido RAMírez, Manuel: «Teoría y Práctica del grupo parlamentario», Revista de Estudios Políticos, núm. 11, 1979, pág. 82.

${ }^{73}$ Idem, pág. 209. Podemos traer a colación un caso reciente en el momento de la elaboración de este trabajo. La polémica entorno a la abstención del Grupo Socialista en el Congreso en la sesión de investidura del candidato a Presidente del Gobierno, mariano Rajoy que tuvo lugar el día 29 de octubre. En rueda de prensa del día 23 de octubre de 2016 declaraba Javier Fernández, presidente de la Gestora del PSOE que iba a trasladar al grupo parlamentario socialista que tenían que abstenerse en dicha sesión añadiendo que «hay algo imperativo»en la resolución adoptada por dicha gestora. Diario El Mundo.

http: //www.elmundo.es/espana/2016/10/23/580cc79348aeb45c3.html (acceso el 14 de noviembre de 2016). 
las listas electorales, y no por sus condiciones personales carece de legitimidad última para seguir líneas divergentes de los partidos y de los grupos o fracciones parlamentarias, con lo cual no sólo se justifica la sumisión de su voto a las decisiones de éstos sino que el mandato libre se muestra en oposición a la moderna democracia de partidos ${ }^{74}$

En el debe de los partidos procede anotar la falta de democracia interna, y con los matices que quieran introducirse, lo cierto es que como señala Michels tienden a que su organización sea oligárquica ${ }^{75}$. $\mathrm{Al}$ respecto cabe señalar, por una parte, que, efectivamente, el partido está controlado por una élite que toma las decisiones por lo que no hay verdadero debate abierto fuera de ese grupo; por otra, y lo que tiene una trascendencia capital: aunque íntimamente relacionados, partido político y grupo político son dos realidades diferentes. Este segundo, y sólo él, agrupa a los representantes elegidos por el electorado, goza así de una legitimidad de la que carece, de acuerdo con la teoría clásica de la representación, el partido político, mero canalizador de la voluntad popular. Las decisiones deberían adoptarse en el seno del grupo, no del partido, pero no es así. Advierte Duverger que la democracia exige que los parlamentarios tengan precedencia sobre los dirigentes del partido pero ello no es así. El dominio del partido sobre sus miembros electos constituye una forma de oligarquía que ese autor califica de "externa», en relación con la naturaleza oligárquica de los jefes dentro del partido. ${ }^{76}$ La subordinación del primero al segundo es absoluta. El partido, mejor dicho, sus dirigentes, controlan al grupo, no hay más que ver lo sucedido tras las elecciones generales del 20-D: las estrategias de pactos, vetos, acuerdos, fijación de líneas rojas, etc. han sido adoptadas por los órganos de los distintos partidos (ni siquiera por sus bases) y no por los grupos parlamentarios. Los partidos se arrojan la representatividad y sus líderes trasladan a la opinión pública el mensaje de que el partido y, en concreto ellos en persona, han recibido el mandato de los electores para actuar en un sentido o en otro. Lo malo es que cada uno entiende que las instrucciones que han recibido del electorado como mejor le conviene: que haya cambio, que haya continuidad, que pacten las fuerzas constitucionalistas, que pacten las fuerzas de izquierda... Por otra parte puede existir una discrepancia entre partido político y grupo político como lo sucedido en el caso de transfuguismo de Benidorm

${ }^{74}$ Citado por García Pelayo, Manuel en El Estado de Partidos, incluido en el vol. II de sus obras completas editado por el Centro de Estudios Constitucionales, Madrid, 1986, pág. 2015.

${ }^{75}$ Michels, Robert: Los partidos políticos, Amorrortu editores España, 2006.

${ }^{76}$ Duverger, Maurice: Los partidos...op. cit. pág. 211. 
en la que el partido mantuvo una postura negativa a apoyar la moción de censura y el grupo municipal una postura positiva. En plena pantomima, los concejales se mantuvieron leales al grupo y se dieron de baja del partido. Y califico de pantomima lo acaecido pues en los siguientes comicios, esos mismos concejales encabezaron la lista del partido, eso sí como «independientes».

En este escenario, el representante, pragmático, lo tiene claro: entrega su lealtad al partido y al líder, no al pueblo soberano o al electorado que ha depositado su voto. Si el representante diligente la vida y hacienda al partido debe dar, la realidad es que la lealtad que es patrimonio del alma también es para el partido. Ya Max Weber advertía que la experiencia enseña «que la medida de la sumisión frente al aparato y el grado de «comodidad» que ofrece el subordinado para el superior constituyen las cualidades que garantizan el ascenso de la manera más segura» ${ }^{77}$. Y así señala Oscar Alzaga que "para que el cargo electo sea un mero eco de la dirección del partido su única cualidad útil es la de la lealtad incondicional; el parlamentario ideal podría acabar por ser un perro de buena raza ${ }^{78}$. Esa lealtad sumisa pero interesada se extiende al líder que, sin embargo, se verá privado de ella si los resultados electorales (la tiranía de los votos) no le son propicios. Siempre hay alguien, cercano a él y que normalmente le ha mostrado públicamente su lealtad, que quiere ocupar su puesto. El cesarismo del líder incluye la posibilidad de ser políticamente eliminado por aquellos que le rodean ( $t u$ quoque Brute, filii mei) ${ }^{79}$. En este sentido dirá Schumpeter que los miembros destacados del partido «adoptan una línea de conducta intermedia entre una adhesión incondicional a la pauta del leader y el establecimiento incondicional de una pauta propia, sopesando los rasgos y las oportunidades con una meticulosidad que a veces es admirable ${ }^{80}$.

${ }^{77}$ WeBer, Max: Economía y Sociedad, Fondo de Cultura Económica, reimpresión en castellano 1969 , pág. 1108.

${ }^{78}$ Alzaga Villaamil, Oscar et alii: Derecho Político Español según la Constitución de 1978 II, UNED, quinta edición, 2012, pág. 357. Y sin embargo, esa lealtad al partido no es inquebrantable. Tuvimos ocasión de comprobarlo en la sesión de investidura de Mariano Rajoy como Presidente del Gobierno, el 29 de octubre de 2016. A pesar de que el presidente de la Gestora del PSOE había advertido en rueda de prensa tras el Comité Federal del partido del 23 de octubre que los miembros del grupo socialista en el Congreso debían abstenerse y que ello era algo imperativo, obviando lo establecido en el artículo 67.2 CE, se rompió la disciplina de voto, votando en contra de lo mandatado por dicho comité 15 diputados, y dos diputadas acataron la instrucción "por imperativo».

${ }^{79}$ Suceso que no fue sino un choque de lealtades entre la debida a César y la debida al Senado.

${ }^{80}$ Schumpeter, Joseph A.: Capitalismo, socialismo y democracia, Folio 1984, pág. 357. 
En todo caso, en un sistema y en unos partidos democráticos, el poder del líder no es absoluto. No hay aquí líderes carismáticos stricto sensu. Como destaca Panebianco, «en la mayoría de los casos lo que se quiere indicar en el lenguaje común con el término «carisma», no es sino una de las situaciones más normales que pueden darse en política: el gran ascendiente personal que todo líder de éxito adquiere ante sus seguidores. En estos casos el término carisma es usado como sinónimo de "prestigioso» o «respetado» ${ }^{81}$. Al presidente Rodríguez Zapatero se le atribuyó que tenía baraka (bendición divina o suerte providencial) hasta tal punto que sus siglas, $\mathrm{ZP}$, eclipsaron las de un partido, PSOE, hasta que aquella se acabó y su nombre y siglas por un tiempo quisieron ser borradas como le sucedió al faraón Akenatón.

En definitiva, asistimos a una traslación de la lealtad del representante de la voluntad popular o del electorado hacia el partido político, convertido "en el sujeto representado por sus representantes» ${ }^{82}$.

Por lo demás, este debate cobra plena actualidad cada vez que se produce un caso de transfuguismo político, más si éste tiene especial repercusión mediática como fueron el caso Tamayo y Sáez o el caso del Ayuntamiento de Benidorm. Estos casos comportan reacciones sociales, políticas, académicas y jurídicas que terminan por reforzar la posición central de los partidos políticos ${ }^{83}$.

Podemos definir al tránsfuga como aquel cargo representativo que, rompiendo la disciplina de voto, se pone a disposición del adversario político sin que se haya producido un cambio sustancial entre la postura del partido y su oferta electoral, con la intención de provocar un cambio o un bloqueo en el gobierno o su mantenimien-

${ }^{81}$ Panebianco, Ángelo: Modelos de partido, Alianza, 1995, pág. 268.

${ }^{82}$ BASTIDA FREIJEDO, Francisco J.: «Derecho de participación de los representantes y función constitucional de los partidos políticos», Revista Española de Derecho Constitucional, núm. 21, 1987, pág. 221.

${ }^{83}$ Sobre esta cuestión vide por todos Tomás MALLEN, Beatriz: Transfuguismo parlamentario y democracia de partidos, Centro de Estudios Constitucionales, 2002; EsTEBAN, Jorge De: «El fenómeno español del transfuguismo político y jurisprudencia constitucional», Revista de Estudios Políticos, núm. 70, 1990; SantaOlaya Machetti, Pablo y Corona Ferrero, Jesús M. a (Dir.): Transfuguismo político: escenario y respuestas, Civitas, 2009; Presna Linera, Miguel Ángel: «La superación del transfuguismo político en las corporaciones locales como exigencia de una representatividad democrática», Revista de Estudios de Administración Local y Autonómica, núm. 271, 1998; y CATALÁ I BAS, Alexandre: "Transfuguismo y régimen jurídico de los concejales no adscritos ¿Puede, y debe el Derecho sancionar la deslealtad política?», Revista Española de Derecho Constitucional, núm. 101, 2014. 
to. ${ }^{84} \mathrm{Si}$ los versos libres están condenados al ostracismo, la experiencia nos muestra que el tránsfuga rompe su relación de lealtad con el partido a cambio de algo. Normalmente los motivos son espurios, éticamente criticables, pero también pueden existir «tránsfugas éticos» Así, Garcia Roca advierte que no merecería el calificativo de tránsfuga o traidor, por no ser éticamente reprobable, el cargo representativo que abandone el partido o el grupo político tras haber denunciado la creación del GAL o irregularidades urbanísticas en Marbella ${ }^{85}$.

Las reformas que se han llevado a cabo para poner freno a esa patología democrática: artículo 73.3 LBRL en 2003 y artículo 197 LOREG en 2011, así como la adopción del Acuerdo sobre un Código de conducta política en relación con el transfuguismo en las corporaciones locales en 1998, no han hecho sino reforzar el control del partido sobre el representante a la par que los partidos han mantenido una postura farisaica e hipócrita con este fenómeno, rasgándose las vestiduras cuando eran los perjudicados y rebajando el tono, mirando hacia otro lado cuando no alentándolo cuando eran los beneficiados. De hecho, la medida «antitransfuguismo» del art. 197 LOREG ha sido declarada inconstitucional y nula mediante la reciente STC de 21 de diciembre de 2017 (cuestión de inconstitucionalidad núm. 5210-2014), por vulnerar el derecho de participación política del artículo 23.2 CE».

Para concluir este apartado, es menester recordar que todos los intentos para que el partido político pueda apoderarse del escaño ganado por el representante en las elecciones han sido infructuosos. Así, el artículo 11.7 de la ley 39/1978, de 17 de julio, de elecciones locales, que establecía la desposesión del cargo por expulsión fue declarado inconstitucional en la STC 10/1983 de 21 de febrero. Tampoco prosperaron las renuncias en blanco. Una parte importante de la doctrina aboga por la desposesión del cargo en caso de transfuguismo ${ }^{86}$ pero hasta el momento esos intentos se han encontrado con la postura firme de Tribunal Constitucional fiel a la teoría clásica del mandato re-

${ }^{84}$ Catala i Bas, Alexandre: «Transfuguismo y régimen jurídico..., op. cit. pág. 52.

${ }^{85}$ García Roca, Javier: «Representación política y transfuguismo» en SANTOLAYA Machetti, Pablo y Corona Ferrero Jesús M. ${ }^{\text {a }}$ (dirs.): transfuguismo político.... op . cit. pág. 42.

${ }^{86}$ Por todos Bastida Freijedo, Francisco J., «Derecho de participación... op. cit., CaAmaño Dominguez, Francisco: El mandato parlamentario... op. cit.; Blanco Valdés Roberto L.: »Transfuguismo y democracia en la Comunidad de Madrid», Claves de la Razón Práctica, núm. 135, 2003; RuBIo LloRenTe, Francisco: «Vernos como somos», El País, 21 de junio de 2003. 
presentativo $^{87}$ con lo que, se ha dicho, la jurisprudencia del Alto Tribunal favorece el transfuguismo y por lo tanto alienta la deslealtad y la traición.

\section{LA LEALTAD DEL CARGO REPRESENTATIVO CON EL ELECTORADO}

La relación entre elector y electo se ha ido diluyendo con el paso del tiempo. Preeminente en los parlamentos medievales, vigente el mandato imperativo que obligaba al segundo a ser leal al mandato recibido si no quería verse desposeído del cargo, fue pasando a un segundo plano con la sustitución de aquel por el mandato representativo que, por una parte, liberaba al representante de las instrucciones del representado y, por otra, establecía que aquello era no de éste sino de la nación vista como un todo. La aparición y consolidación de los partidos políticos no ha hecho sino ahondar en esta situación. La realidad no muestra que no hay una voluntad nacional unánimemente compartida por los miembros de la sociedad, única, indivisible y común a todos ellos, sino que lo que existe son intereses sectoriales que responden a una sociedad fragmentada de la que los partidos políticos no son sino el reflejo de esta realidad. La teoría clásica del mandato representativo se asienta pues en una fictio a la que, sin embargo, nuestro Tribunal Constitucional se aferra al afirmar en sentencias tales como la 10/1983 que «lo propio de la representación, es el establecimiento de la presunción de que la voluntad del representante es la voluntad de los representados, en razón de la cual son imputados a éstos en su conjunto, y no sólo a quienes votaron en su favor o formaron la mayoría, los actos de aquel», aunque no es ajeno a la realidad al reconocer, por ejemplo en la STC 32/1985, que los representantes lo son también "aunque en otro sentido, de sus electores», en la STC 119/1990 que "no se puede desconocer la fidelidad a los compromisos políticos ofertados a los electores y que han determinado la elección», pero de lo anterior no extrae ninguna conclusión.

En nuestro sistema, la relación elector-electo es mediata a través de la intermediación de los partidos políticos por lo que la lealtad que pueda tener el segundo con el primero está cortocircuitada por dicha intermediación. Si el elector se decanta por unas siglas, sí es comúnmente aceptado que el que se aparta de la disciplina de partido es un

${ }^{87}$ Vide por todos las SSTC 10/1983 de 21 de febrero y 247/2012, de 2 de diciembre. 
desleal, sólo siendo leal al partido se es leal al elector ${ }^{88}$. Si el representante falta a este compromiso pierde la representatividad que está "prefigurada en la oferta electoral de los grupos políticos y seleccionada por los electores en su sufragio». ${ }^{89}$ Ello no obstante nuestro Tribunal Constitucional, STC 10/1983 sigue insistiendo que del artículo 23 $\mathrm{CE}$ nace «una vinculación inmediata entre electores y elegidos que no puede ser condicionada en sus elementos esenciales por la mediación de los partidos».

Tenemos un sistema que favorece el control del partido sobre el electo y provoca la desconexión de éste con el electorado, el cargo prefiere alejarse antes del electorado que de su partido, semper fidelis, por puro instinto de supervivencia política. Muchos reclaman una reactivación de la relación elector-electo. Kelsen ya lo manifestaba en la primera mitad del siglo $\mathrm{xx}^{90} \mathrm{y}$ los movimientos del 15-M hicieron de ello bandera. Una mayor democracia interna de los partidos políticos favorecería esta demanda siempre y cuando las medidas a adoptar no sólo lo fueran de cara a la galería. Como señala Raúl Morodo, si los partidos concurren a la manifestación de la voluntad general y expresan el pluralismo democrático es lógico que su organización interna sea democrática ${ }^{91}$. Si el poder político deriva del pueblo y su ejercicio debe su legitimidad al pueblo y teniendo en cuenta que la influencia del pueblo se transmite esencialmente a través de los partidos, sólo en la medida en que los partidos permanezcan ligados a su base social pueden desplegarse en democracia; por ello, únicamente aquellos partidos que satisfagan en su estructura interna los parámetros democráticos podrán ejercer de manera correcta su función constitucional, tal como señala el tribunal Constitucional alemán ${ }^{92}$. Consultas a las bases, especialmente a la hora de confeccionar los programas electorales y las políticas de pactos (pero no con consultas prefabricadas) y la eliminación de lo que Duverger calificaba de elementos autocráticos en la elección de los representantes ${ }^{93}$, la famosa ley de hierro de la oligarquía de Michels que sigue, más o menos

${ }^{88}$ En este sentido BLANCo VALDÉs afirma que debería resolverse el mandato en el supuesto de abandono del partido o del grupo parlamentario para dar así cumplimiento a la exigencia democrática de mantener el principio de lealtad de aquel representante a los ciudadanos que lo hubieran elegido con sus votos. Blanco Valdés, Roberto: Los partidos... op. cit. Tecnos, 1990, pág. 115.

${ }^{89}$ BASTIDA FreiJedo, Francisco J.: «Derecho de participación...op. cit., pág. 213.

${ }^{90}$ Kelsen, Hans: Valor... op. cit. pág. 67.

${ }^{91}$ Morodo, Raúl: Los partidos políticos en España, Labor, 1979, pág. 13.

92 Vide FERnÁNDEZ VIVAS, Yolanda: «El régimen de los partidos políticos en Alemania», Teoría y realidad Constitucional, n. ${ }^{\circ}$ 31, 2013, pág. 477.

${ }^{93}$ Duverger, Maurice: Instituciones Politicas y Derecho Constitucional, Ariel, 1970, pág. 128. 
atemperada, vigente. Los candidatos, no sólo el líder nacional para el que se le preparan unas primarias, deberían ser elegidos de abajo a arriba y no al revés, como sucede actualmente. Y así dirá Touraine que la corrupción más fuerte es la que permite a los partidos políticos elegir a sus dirigentes de forma endogámica ${ }^{94}$.

Otro de los mecanismos para potenciar la relación elector-electo sería, para algunos, la disminución del tamaño de las circunscripciones. Con ello el electo se identificaría más fácilmente con los intereses de su electorado. En estos momentos, el representante no tiene forma de identificar claramente a sus electores sino a través de lo que le transmite el partido. Con ello se propiciaría la aparición de una figura similar al backbencher propio del Parlamento británico. El parlamentario que no forma parte del gobierno ni del núcleo duro del partido pero que en un momento dado puede mostrar su disconformidad con el parecer del partido si éste va en contra de los intereses de su electorado. En estos casos reaparece la lealtad del electo hacia el elector, que se antepone a la que aquél profesa al partido. Pero tampoco nos llevemos a engaño. En la mayoría de los casos, el diputado tomará la decisión tras un cálculo de lo que le es más rentable desde el punto de vista político. Mantendrá pues, una u otra lealtad por razones egoístas o, si queremos llamarlo de otra manera, utilitaristas, no altruistas. Por otra parte, si el diputado atiende a los intereses del electorado de su distrito, ¿Quién atiende los intereses generales? Con ello no quiere afirmarse que en los sistemas mayoritarios con circunscripción uninominal, el papel del partido sea secundario sino que simplemente en estos casos el papel del candidato adquiere mayor protagonismo que en los sistemas proporcionales en los que, salvo el cabeza de lista en todo caso, el papel del resto de candidatos queda eclipsado totalmente por las siglas del partido. Y es que como señala Blanco Valdés siguiendo a Claudio Rossano, «de hecho sólo los candidatos apoyados por los partidos aparecen como competidores reales $»^{95}$.

Queda por último la cuestión de la revocación. Parte importante de la doctrina se inclina porque el cargo representativo sea desposeído en caso de transfuguismo, abandono del partido o, incluso expulsión ${ }^{96}$. Ello no obstante, como hemos visto, el Tribunal Constitucio-

${ }^{94}$ Touraine, Alain: ¿Qué es la democracia?, Ensayo, 1994, pág. 177.

95 Blanco Valdés, Roberto Luís: Los partidos políticos, Tecnos, 1990, pág. 82.

${ }^{96}$ Vide por todos Rubio LloRENTE, Francisco: «Vernos como... op. cit., Esteban Jorge DE: «El fenómeno español... op. cit. pág. 31; Blanco Valdés, Roberto L.: «Transfuguismo y democracia... op. cit. pág. 50; BASTIDA FreJEIDO, Francisco L.: «Derecho de participación...op. cit. pág. 216 y CAAMAÑo DomíngUEZ, Francisco: El mandato...op. cit. pág. 237. 
nal, ajeno un tanto a la realidad, se mantiene firme en la idea de que existe una relación directa entre representante y representado de lo que deduce que el mediador, partido político, no puede poner fin en ningún caso a dicha relación. Ahora bien, abre la puerta a que la revocación pude proceder del cuerpo electoral. Así, en la STC 5/1983 advierte que «el cese en el cargo público representativo (...) no puede depender de una voluntad ajena a la de los electores y eventualmente a la del elegido» siendo una opción válida la reintroducción del mandato imperativo en manos del cuerpo electoral. Advierte con acierto Bastida de que el Alto Tribunal al afirmar en dicha sentencia que «la permanencia en el cargo no puede depender de la voluntad de los partidos sino de la expresada por los electores a través del sufragio expresado en elecciones periódicas» parece insinuar la existencia de una «especie» de facultad de revocación cuando lo cierto es que la permanencia del representante no depende de la voluntad de los electores, ya que la representación no decae cuando al representante no se le renueva su mandato en las siguientes elecciones a las que, incluso puede no concurrir. ${ }^{97}$

De ahí que, en mi opinión, sea inconstitucional la reciente modificación de la Ley 9/2010 de 7 de julio de la Generalitat, de Designación de Senadores o Senadoras en representación de la Comunitat Valenciana, producida por la ley 10/2016, de 29 de octubre, que introduce en el artículo 14 como causa de cese la «revocación de la designación acordada por el pleno de Les Corts Valencianes», regulándose el procedimiento en un nuevo artículo 14 bis que exige una mayoría de dos tercios de los miembros de la cámara y «que no se produzca ningún voto negativo entre los diputados o diputadas que sean miembros del grupo parlamentario proponente del senador o senadora». Con ellos se deja, en último término, la revocación en manos no ya de la cámara sino de los grupos parlamentarios. Olvida el legislador valenciano que todos los Senadores gozan del mismo estatus, que deben estar sometidos al mismo régimen y que todos lo son en representación del pueblo valenciano, unos elegidos directamente por éste y otros, los territoriales, a través de les Corts. Es muy discutible que una institución, en este caso les Corts, pueden revocar miembros de otra institución, en este caso el Senado. Tal reforma supone la introducción de un mandato imperativo prohibido por el artículo $67.2 \mathrm{CE}^{98}$.

${ }^{97}$ Bastida Frejeido, Francisco L.: «Derecho de participación... op. cit., pág. 204.

${ }_{98}$ Me congratulo de comprobar, ya en imprenta el presente trabajo, que efectivamente el Tribunal Constitucional ha confirmado la postura que aquí defiendo, mediante su STC 123/2017, de 2 de noviembre, cuyo análisis detallado acometeré en otra sede. 
Es cuanto menos chocante que los diputados de Les Corts Valencianes que no pueden ser revocados por los ciudadanos que los eligen se arroguen la facultad de revocar a miembros de otra institución representativa como el Senado. Unos senadores han sido elegidos directamente por el cuerpo electoral, otros por el Parlamento autonómico. Si el electorado no tiene la facultad de revocarlos mucho menos lo tiene el Parlamento autonómico en cuestión. El pueblo les ha otorgado a los diputados autonómicos el poder o mandato para elegir a los Senadores territoriales pero no el de revocarlos. Los senadores territoriales una vez elegidos se desligan de la institución que los nombró para formar parte de otra, el Senado, de tal suerte que aquella pierde toda posibilidad de mandarle ningún tipo de instrucción u orden. Si se abre esta espita, al Senador se le exigiría, en definitiva, una nueva lealtad, la que debería a la institución que lo nombró, que puede entrar en conflicto con la que debe a su partido, al electorado o, incluso, a la institución de la que forma parte. A nadie escapa que esta modificación se introdujo con la clara intencionalidad política de destruir a una Senadora territorial de la Comunitat Valenciana por lo que subrepticiamente esa es una ley ad hoc vulneradora de los artículos $23.2 \mathrm{CE}$ que exige que los cargos representativos puedan desempeñar con normalidad sus funciones sin presión de ningún tipo proveniente de otra institución y del artículo 67.2 CE que prohíbe el mandato imperativo. Añadir que en dicha reforma se elimina por «intrascendente», la comparecencia previa ante una Comisión de les Corts de los candidatos en la que podía ser requerida su opinión sobre cuestiones de índole política que afectasen a la Comunitat Valenciana, nunca por cuestiones de carácter personal. Dicho trámite, introducido en 2010, tenías interés, entre otras cosas, porque permitía a los grupos parlamentarios trasladar a los candidatos preguntas formuladas desde la sociedad civil. Llama la atención que en el procedimiento de introducido en el 14 bis se prevea la comparecencia obligatoria del Senador/a en cuestión a fin de que dé las explicaciones oportunas pero, sin embargo, no se desee dicho trámite para su nombramiento. Síntoma, en mi opinión, de las reticencias de los partidos a abrirse a la sociedad y al ser transparentes en sus nombramientos. Prefieren el sistema tradicional de componendas (tú apoyas a mis candidatos a cambio de que yo apoyo a los tuyos) sin mayores explicaciones, lo que, en definitiva es una muestra más de los tics oligárquicos que siguen arrastrando los partidos. Ya no solo quieren controlar el nombramiento de los senadores territoriales sino que quieren extender su poder sobre su cese.

En las manifestaciones de los indignados, del 15M, etc..., se cuestionaba si los representantes políticos lo eran verdaderamente de la 
ciudadanía ${ }^{99}$. Se distinguirá así una legitimidad de origen, que otorgarían las urnas y una legitimidad por el ejercicio que se mantiene o se pierde según el actuar del cargo. En la sentencia de la Audiencia Nacional 31/2014, de 7 de julio que juzgaba el asalto al Parlament de Catalunya, este tribunal implícitamente consideró que los diputados catalanes habían o estaban a punto de perder su legitimidad de origen si votaban a favor de las medidas económicas propuestas por el Govern catalán (es decir, quedaban deslegitimados por su ejercicio) y que los manifestantes estaban imbuidos de la potestad de desposeer de la legitimidad de origen a los cargos representativos. Así afirmó que: «Quienes protestaban no querían las restricciones económicas de las prestaciones y de los servicios públicos; y quienes adoptaban tales decisiones ya no les representaban. Mensajes directamente relacionados con la Constitución social (...) y con la Constitución democrática, en la medida que requerían a los representantes políticos, a los diputados, para que respondieran a los intereses generales, a los de la mayoría de la sociedad, y cuestionaban la legitimidad de ejercicio de su propia representación» para seguir diciendo que «desde esa perspectiva conviene hacer notar que la protesta suponía la defensa de la Constitución y de sus contenidos básicos» y concluir que los manifestantes estaban en posesión de una especie de mandato imperativo con las siguientes palabras: «en alguna medida, la protesta se dirigía al corazón del concepto y del modo de ejercicio de la democracia en nuestros sistemas (...). La protesta que ejercían moldeaba algo parecido a lo que, bien es cierto que en pocos momentos de la historia de las sociedades, se ha conocido como acción revocatoria de mandatos, una forma de intervención democrática directa para el control de la representación», todo y reconocer que nuestra Constitución prohíbe el mandato imperativo.

La verdad es que no veo la relación entre la protesta y una acción revocatoria. Una protesta en la calle no moldea nada parecido a una acción revocatoria de mandatos. No creo que pueda revocarse a nadie mediante una manifestación por muy multitudinaria que sea. Ello supondría legitimar la Marcía su Roma. Al igual que no puede deducirse que quien no acude a la manifestación implícitamente está dando su aprobación a las medidas adoptadas. Los ciudadanos que acu-

${ }^{99}$ Crítico con estos movimientos se mostraba PECES-BARBA, Gregorio: «Los indignados y la democracia», El País, 13 de septiembre de 2011:» los jóvenes indignados son en general personas de buena fe, que denuncian problemas reales, pero que tienen tan alta opinión de sí mismos que no respetan el pluralismo ni otras opiniones diferentes, y que, con una soberbia desmesurada, creen que pueden partir de cero y reinventar una democracia asamblearia, sin partidos ni elecciones por sufragio universal» concluyendo que «no creo que con esas premisas tengan ni adhesiones ni futuro. Además el peligro del fascismo, al menos en las formas, está presente». 
den a una manifestación se representan a sí mismos pero no pueden pretender representar ni a todo ni a parte del cuerpo electoral. No opina así la Audiencia Nacional que considera que los participantes en el piquete que se «confrontaba con los diputados del Parlament de Catalunya» «se erigían en portavoces de un sector de la sociedad». Ante ello cabe preguntarse quién y a través de qué mecanismos les había sido atribuida tal facultad. El argumento de la Audiencia es del todo erróneo y nos llevaría a reconocer la existencia de una confrontación entre unos representantes de parte de la sociedad, anónimos, sin poder esgrimir título habilitante de esa representación y unos representantes con nombres y apellidos de esa misma sociedad, elegidos unos meses antes en las urnas. No puede la Audiencia poner en un plano de igualdad a unos y a otros. ¿Dónde reside la legitimidad de origen de los primeros? En todo caso, serían los legítimos representantes o portavoces de las entidades convocantes de la manifestación los que podrían hablar en nombre de éstas y sólo de éstas, no en nombre de la sociedad. La legitimidad o bondad de los objetivos perseguidos en la manifestación, compartir sus ideas o reivindicaciones, por muy mayoritario que sea ese sentimiento entre la ciudadanía, no es título suficiente para arrogarse unos participantes en ella la representación de una parte de la sociedad. En cualquier caso, esta sentencia de la Audiencia Nacional ha sido casada y anulada por el Tribunal Supremo en la suya 161/2015, de 17 de marzo.

Aunque la Constitución prohíbe el mandato imperativo, nuestro Tribunal Constitucional se ha encargado de matizar, STC 10/1983 de 21 de febrero, que «la idea de representación va unida a la de mandato libre, no es teóricamente inimaginable un sistema de democracia mediata o indirecta en la que los representantes estén vinculados al mandato imperativo de los representados». Puede pensarse en una revocación del mandato. Como advierte acertadamente Torres del Moral, «la revocación puede insertarse en el mandato representativo por el deterioro o la pérdida de confianza que el cuerpo electoral, la nación, depositó en los representantes ${ }^{100}$. Esa revocación podría proceder única y exclusivamente del cuerpo electoral no de los partidos políticos y es que, tal como recuerda este autor, el Tribunal Constitucional «no estima frontalmente la ilícita revocación por parte de los electores, sino la proveniente de los partidos políticos» ${ }^{101}$. De todas maneras, considera que «la inserción de esta nueva pieza en el siste-

100 TorRes Del Moral, Antonio: «Requiem por el mandato representativo», Revista de Derecho Político, núm. 81, 2011, págs. 45 y 46.

${ }^{101}$ Idem, pág. 46. 
ma es dificilísima, técnicamente muy difícil y acaso presentara más inconvenientes que ventajas» ${ }^{102}$.

Se oyen voces a favor de la introducción de la revocación mediante la recogida de un número de firmas suficientes para ello ${ }^{103}$. Hay que asegurarse mucho a la hora de decidir introducir esta figura. Puede convertirse en un arma peligrosa en mano de la mayoría para silenciar a los diputados de las minorías y, en cambio, en algo inofensivo en manos de las minorías. Los partidos mayoritarios siempre tendrán más posibilidades de recoger el número de firmas necesario para revocar el mandato de un diputado de un partido minoritario que viceversa. Las consecuencias son casi nulas ya que le sustituiría el siguiente de la lista, tan fiel a los dictados del partido como el recién sustituido. Por otra parte, habida cuenta que son todos los diputados del partido en el gobierno los que apoyan sus decisiones sería necesario revocar a todos ellos, lo que carece de sentido. Lo cierto es que se puede producir un conflicto de lealtades que puede llevar a desquiciar al cargo. ¿A quién obedece, al electorado que le votó o al partido bajo cuyas siglas se presentó?

Nos encontramos ante un callejón sin salida. Como pone de relieve Pedro De Vega, por una parte, la esencia de la política parlamentaria es la deliberación y ello excluye cualquier forma de mandato imperativo, por otro lado, «en la medida en que el mandato representativo impone un distanciamiento y una separación obligada entre representante y representado, de la discusión parlamentaria quedarán marginados la práctica totalidad de los ciudadanos del Estado» ${ }^{104}$. Además, un cargo representativo ha de adoptar gran número de decisiones: votar una nueva ley sobre el aborto, una ley sobre la abdicación del monarca, una ley sobre subida o bajada de impuestos, otra sobre recortes sociales, otra sobre transparencia, etc... Su voto siempre será cuestionado por aquella parte de la ciudadanía que no comparta sus posicionamientos. No existe una opinión pública en el sentido de opinión uniforme y generalizada en el seno de la socie-

102 Ídem 47.

${ }^{103}$ En este sentido la Proposició de llei de transparencia, accés a la información pública i bon govern que está en tramitación en el Parlament de Catalunya prevé en su artículo 81 como sanción muy grave por incumplimiento de las obligaciones que establece la ley, la destitución del cargo pero excluye de la misma a los cargos representativos pero algunos dirigentes están a favor de introducir la revocación en los términos expuestos. Solución a la que ya se refería TORRES DEL MoRAL, Antonio: «La crisis del mandato representativo en el Estado de Partidos», Revista de Derecho Político, núm. 14, 1982, págs. 28 y ss.

${ }^{104}$ VEGA, Pedro DE: «Legitimidad y representación en la crisis de la democracia actual», Working Paper, núm. 141, Barcelona, 1998, págs. 9-10. 
dad. Sobre una cuestión hay muchas opiniones públicas, sectoriales, tantas como grupos sociales resulten afectados por la misma. Por otra parte, la generación de una opinión no es en muchos casos neutra. No descubrimos nada si afirmamos que muchas opiniones que reciben el calificativo de públicas, sumando gran número de adeptos entre la ciudadanía son dirigidas por importantes grupos de presión que permanecen en la sombra y se canaliza a través de los grandes grupos mediáticos que no permiten, al ser intransitivos, un verdadero intercambio de ideas. De ahí que la opinión pública como opinión única y universal, libremente formada en la sociedad no existe más que en un plano ideal y, por lo tanto, no puede convertirse en un tribunal que da y quita legitimidades. Como afirma De Vega, «el enfrentamiento entre representación y opinión, en el que teóricamente quedaría expresado el posible conflicto entre la legitimidad de origen y la legitimidad de ejercicio en la democracia contemporánea, lo que realmente manifiesta cuando se produce es la confrontación entre poderes públicos (surgidos de la representación democrática de los ciudadanos) y poderes privados (creados en la competencia del mercado)» ${ }^{105}$.

En definitiva, el elector en nuestro sistema, puede castigar la deslealtad del partido no otorgándole su confianza en los siguientes comicios no así al representante al que no puede revocar en ningún caso. Si es el partido el que controla la vida política pues como destaca Pedro De Vega existe una descolocación de la política ya que «Parlamento y Gobierno como lugares de decisión han sido sustituidos por Comités y Ejecutivas de los partidos» ${ }^{106}$ es a ellos a quienes se les debe juzgar si han sido leales al electorado viendo, entre otras cosas, el grado de cumplimiento de su programa electoral, y no a los representantes, maniatados por un mandato de partido que ni quieren ni pueden romper. En este sentido, cada nueva elección es como una reválida especialmente para el partido o partidos que han sustentado al gobierno, aunque también para los que han ejercido la oposición.

\section{V. ¿ES POSIBLE ESTABLECER UNA GRADUACIÓN DE LEALTADES DEL CARGO REPRESENTATIVO?}

El representante, en el ejercicio de su cargo, genera una serie de relaciones políticas que, como hemos señalado ha de abordar desde la bona fides, sin traicionar al que está al otro extremo de la relación. Aquí he hecho referencia, en un ejercicio de simplificación, a tres de

${ }^{105}$ VEGA, Pedro DE: «Legitimidad y representación... op. cit. pág. 20

${ }^{106}$ Idem. 
ellas. Así, en un régimen democrático se le exige, en mayor o menor medida, con unas consecuencias u otras, una lealtad a la constitución democrática, otra al partido político y una última al electorado. ${ }^{107}$ En el transcurso de una legislatura, sin un proceso constituyente abierto, podríamos establecer la siguiente jerarquización de lealtades: a la constitución democrática, al electorado y al partido político. Abierto un proceso constituyente las cosas podrían cambiar pues cabe preguntarse hasta qué punto el representante debe ser leal a una constitución que se desea cambiar. Ello tiene especial importancia en una democracia. Pero incluso en ese caso el principio democrático del resultado es intocable. Y es que, como advierte Sartori, hay que distinguir el ideal democrático sin un sistema democrático y el ideal democrático en el marco de una democracia ${ }^{108}$.

No soy de la opinión de que la democracia tenga el poder de destruirse. El demos en el ejercicio del kratos no lo puede todo, especialmente abdicar del kratos en favor de un dictador. Por lo tanto el demos ha de ser leal en todo momento a la democracia pero como afirma Held hay que ser cauto a la hora de responder a la pregunta de si se puede confiar en un demos esencialmente democrático ${ }^{109}$ y es que como recuerdan muchos autores, los regímenes totalitarios han contado con apoyos de una parte más o menos amplia del demos. ${ }^{110}$ En 1984 se mostraba escéptico Elías Díaz con esta posibilidad. Ante la pregunta « ¿Y si una mayoría (o la unanimidad) decide un día renunciar a su soberanía, a su libertad, y entregarse atada de pies y manos a la despótica voluntad de un omnipotente dictador?» Ante esta pregunta responde que «la dictadura de Hitler llegó en realidad a través de la imposición de la fuerza y a través del terror y la intimidación (...) Con libertad en la decisión difícilmente se da como resultado fáctico la opresión ${ }^{111}$.

No creo que estuviese de acuerdo con esta reflexión Loewenstein, que basa su teoría de la democracia militante en impedir que los parti-

${ }^{107}$ Simplificación porque no he tratado por ejemplo la lealtad al partido político y al grupo municipal o parlamentario, lealtades que estuvieron enfrentadas en el caso de transfuguismo de Benidorm o la lealtad en el caso de coaliciones electorales o la lealtad que el cargo representativo debe a la institución de la que forma parte y al resto de instituciones que le llevaría, por ejemplo a no abusar de los privilegios que derivan de su pertenencia y deslindar claramente lo que es el ejercicio del cargo público de lo que es el del cargo político y no utilizar aquellos en el segundo caso.

${ }^{108}$ SARTORI, Giovani: Teoría...op. cit. pág. 98.

${ }^{109}$ Held, David: Modelos de democracia, Alianza, 1992, pág. 317.

${ }^{110}$ En este sentido ZAN, Julio de: «Significación moral de la democracia», pág. 301, en VVAA: Ética comunicativa... op. cit.

${ }^{111}$ DíAz, Elías: De la maldad estatal y la soberanía popular, Editorial Debate 1984, pág. 65 . 
dos políticos, utilizando los mecanismos del proceso democrático se hagan con el poder y acaben con la propia democracia «el fuego ha de combatirse con fuego", versión actualizada de "pas de liberté pour les ennemis de la liberté». ${ }^{112}$ Todos tenemos en mente los discursos de Hitler afirmando que si se hacía con el poder prohibiría el resto de partidos políticos y acabaría con el régimen democrático alemán. Hoy Europa asiste estupefacta al resurgimiento de partidos con nulas convicciones democráticas, xenófobos y racistas. Se extienden como una plaga por todos los países: Francia, Alemania, Grecia, Austria, Holanda... En este sentido afirma Touraine que es impensable una vuelta al hitlerismo en Europa pero, «sería peligroso quedarnos en estas afirmaciones optimistas pues en numerosos países se observa la presión constante de categorías sociales que se sienten amenazadas e intentan protegerse expulsando a los extranjeros o a las minorías.» ${ }^{113}$ Va más allá Dahl al afirmar que «probablemente bastaría una amplia minoría de antidemócratas violentos y militantes para destruir la capacidad de un país para mantener sus instituciones democráticas.» ${ }^{114}$ La lealtad democrática del Frente Nacional, Amanecer Dorado, el Partido de la Libertad (PVV), Alternativa para Alemania (AfD) y de sus líderes y cargos representativos, algunos con escaño en el propio Parlamento europeo, es escasa por no decir nula. Cierto es que estos líderes (Marie Le Pen, Frauke Petri, Geert Wilders), no se presentan ante la opinión pública con camisas pardas y levantando el brazo. Huyen de la parafernalia nazi (Amanecer Dorado puede ser una excepción) pero no son más que lobos disfrazados con piel de corderos. ${ }^{115}$ Estamos dejando Europa en manos de los intolerantes y como decía Popper «hay una insensatez, la intolerancia, difícil de tolerar: en realidad es aquí, donde encuentra su límite la tolerancia. Si concedemos a la intolerancia el derecho a ser tolerada, destruimos la tolerancia y el Estado Constitucional ${ }^{116}$.

Decíamos que en una situación normal, sin un proceso constituyente abierto, podríamos establecer la siguiente graduación: lealtad hacia la constitución democrática, o, en concreto, hacia las cláusulas de esa constitución que encarnan el principio democrático; en segundo lugar, lealtad al electorado y por último la lealtad al partido. Esto en un plano ideal. Otra cosa es pasar al plano real que trastoca el or-

112 Loewenstein, Karl: «Militant Democracy and fundamental rights I/II», American political science review, núm. 31, 1937.

113 Touraine, Alain: «la caída de la socialdemocracia», El País, 24 de abril de 2002

${ }^{114}$ DAHL, Robert: La democracia. Una guía para los ciudadanos, Taurus, 1999, pág. 179.

${ }^{115}$ Vide CATALA I BAS, Alexandre H.: La (In)tolerancia en el estado de derecho, Revista General de Derecho, 2002, págs. 83 y ss.

${ }^{116}$ Popper, Karl: En busca de un mundo mejor. Paidos, 1994, pág. 244. 
den de la segunda y tercera lealtades, pasando al segundo lugar la lealtad al partido y relegando al último lugar la lealtad al electorado y ello porque el partido se presenta como todopoderoso y, en cambio, gran parte del electorado tras las elecciones se desentiende y se vuelve apático, lo que Aranguren denominaba una democracia hacedera consistente en votar periódicamente y tras ello, hacer dejación de los asuntos en manos de los políticos profesionales ${ }^{117}$. Ante esta situación el representante podrá traicionar a la primera asumiendo un discurso antidemocrático lo que le puede acarrear la expulsión del partido, hecho que posiblemente no le preocupe en demasía pues puede tener preparado su desembarco en algún partido populista en auge; podrá traicionar la que debe al partido, convirtiéndose, en su caso, en tránsfuga, normalmente porque va a obtener una mejora personal y/o política y/o económica (salvo que se trate de un tránsfuga ético). Puede, por último faltar a la lealtad debida al electorado, tanto traicionando al partido al que el electorado otorgó su confianza como manteniéndose fiel al partido a pesar de que éste incumpla de forma grave las promesas hechas a aquél, deslealtad del partido de la que nadie quiere oír hablar.

\section{VI. ¿LEALTAD DEMOCRÁTICA EN PELIGRO? UNA BREVE REFLEXIÓN FINAL}

En un mundo global, no hay sociedades homogéneas ni un interés general unánimemente asumido. Las sociedades se encuentran fragmentadas y los intereses que pretenden los diferentes grupos son distintos e, incluso, antagónicos. Como advierte Dalh «cuanto mayor y más abarcadora es una unidad política más tienden los habitantes a mostrar diversidad en aspectos que tienen que ver con la política: sus lealtades locales y regionales, su identidad étnica y racial, su religión, creencias políticas e ideológicas, ocupación, estilos de vida, etc... ${ }^{118}$ " ahora la noción de bien común se ha extendido más sutilmente a fin de abarcar los heterogéneos apegos, lealtades y creencias de un gran conjunto de ciudadanos, con una multiplicidad de divisiones y conflictos entre ellos ${ }^{119}$. En este escenario, la lealtad política no es la única existente. Han cobrado fuerza lealtades antiguas que se mezclan

${ }^{117}$ ARANGUREN José Luis: «Ética comunicativa y democracia» en VVAA, Editorial Crítica, 1991, pág. 211. Vide también, entre otros, HeLd, David: Modelos... op. cit. pág. 192; TourAINE, Alain: ¿Qué es la democracia?...op. cit. pág. 285; SARTORI, Giovani: Teoría... op. cit. pág. 141.

118 DalH, Robert A.: La democracia y sus críticas, Paidos, 1993, pág. 262.

${ }^{119}$ Idem pág. 262. 
con ésta. Me refiero, por ejemplo a la lealtad religiosa y a la lealtad atávica al pueblo. En cuanto a la primera, en Europa, en la que los cristianos estuvieron sujetos a esa doble lealtad se ha intentado (recordemos a Guillermo de Occam o a Marsilio de Padua) con mayor o menor éxito mantenerlas en planos diferentes (aun así la reina de Inglaterra es a la vez cabeza de la Iglesia anglicana). Es una realidad que la lealtad religiosa influye en determinadas decisiones políticas de los cargos representativos (ejemplo: votar una ley sobre el aborto o sobre el matrimonio de personas del mismo sexo). En estos casos, excepcionalmente el partido deja libertad de voto a aquellos a fin de que voten «en conciencia» con lo que lo que debería ser la regla general, que el representante que no está sujeto a mandato imperativo votara según los dictados de su conciencia, teniendo como objetivo no traicionar la confianza (trust) que los electores han depositado en él se convierte en excepción. Preocupante es la superposición de la lealtad política y religiosa en países de mayoría musulmana. Ejemplo claro lo tenemos en Turquía con partidos políticos y representantes islamistas. Así, en su momento fue ilegalizando el Refah Partisi por el Tribunal Constitucional turco, por pretender la instauración de un régimen teocrático con la reintroducción de la sharia y la defensa de la yihab como método político, ilegalización que fue respaldada por el Tribunal Europeo de Derechos Humanos en sentencia de sala de 31 de julio de 2001 y de la Gran Sala de 13 de febrero de 2003.

Esta cuestión engarza con la segunda lealtad que ha aparecido con fuerza en Europa, fruto del populismo. La lealtad al volk, invocándose un espíritu del pueblo: un volkesgeist o una volkeele, que parece una super-alma. Como señala Sartori «partiendo de la idea del pueblo como un todo orgánico puede fácilmente inferirse que cada individuo no cuenta nada ${ }^{120}$. Los espectaculares resultados del Frente Nacional en Francia, de la AFD en Alemania, donde se llega a afirmar abiertamente que el islam no forma parte de este país nos deben hacer ver lo preocupante de la situación. ¿Cómo es posible esta contra-ola antidemocrática? Decía Don Gregorio, el maestro, en La lengua de las mariposas que «si conseguimos que una generación crezca libre en España ya nadie les podrá arrancar nunca la libertad, nadie les podrá robar ese tesoro" ¿Cómo es posible que en Europa una generación que ha vivido en democracia, que ha oído relatar a sus mayores los horrores a que conduce ese tipo de lealtad, reniegue de la democracia y se refugie en esa lealtad antidemocrática? De ahí que como defiende Julio De Zan: «la formación de una conciencia moral esclarecida acerca de la validez moral del sistema democrático, y la difusión de conviccio-

${ }^{120}$ SARTORI, Giovani: Teoría de la democracia ... op. cit. pág. 45. 
nes fundadas en argumentos capaces de resistir la seducción contrarias, aun en situaciones de crisis, nos parece ser una de las condiciones para la consolidación y fortalecimiento del sistema» ${ }^{121}$ y es allí donde de la lealtad democrática de los cargos representativos debería derivarse la obligación de una actividad positiva y pedagógica de defensa de la democracia.

${ }^{121}$ DE ZAN, Julio: «Significación moral de la democracia» VVAA: Ética comunicativa y democracia, editorial crítica, 1999, pág. 300. 